Supporting Information for

\title{
Tuning the Double Gyroid Phase Window in Block Copolymers via Polymer Chain Conformation Near the Interface
}

\author{
Beihang Yu, Ruipeng Li, ${ }^{\dagger}$ Rachel A. Segalman ${ }^{\dagger, *}$ \\ ${ }^{\dagger}$ Department of Chemical Engineering, University of California, Santa Barbara, Santa Barbara, \\ California 93106, United States \\ ${ }^{\ddagger}$ National Synchrotron Light Source II, Brookhaven National Laboratory, Upton, New York \\ 11973, United States \\ *Corresponding author: R.A.S. (segalman@ucsb.edu)
}

\section{Contents}

Polypeptoid Characterization

Polystyrene Characterization

Block Copolymer Characterization

In-situ Temperature SAXS Characterization

Supplemental Calculations 


\section{Polypeptoid Characterization}<smiles>COCCN</smiles>

2-methoxyethylamine<smiles>COCCN(C)CC(=O)C(C)(C)C</smiles>

Nme $N$-(2-methoxyethyl)glycine<smiles>C[C@H](N)c1ccccc1</smiles>

$(R)-(+)$ - $\alpha$-methylbenzylamine<smiles>C[C@H](c1ccccc1)N(C)CC(=O)C(C)(C)C</smiles><smiles>NCCc1ccccc1</smiles>

2-phenylethylamine<smiles>CN(C)CC(=O)C(C)(C)C</smiles>

Npe

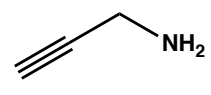

propargylamine

Nprg $N$-(2-propargyl)glycine

Figure S1. Chemical structure of amine submonomers and corresponding $N$-substituted glycine units.

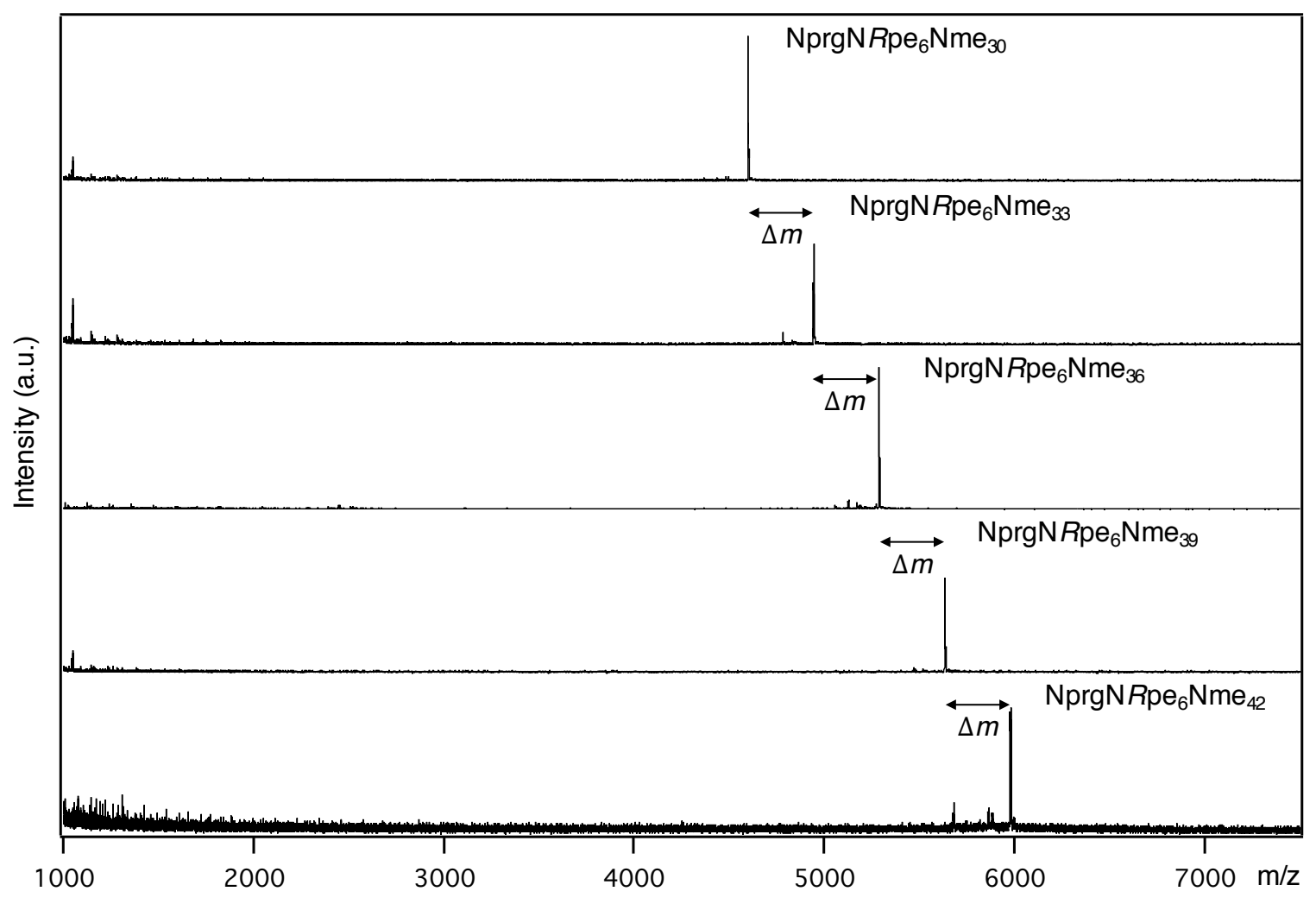



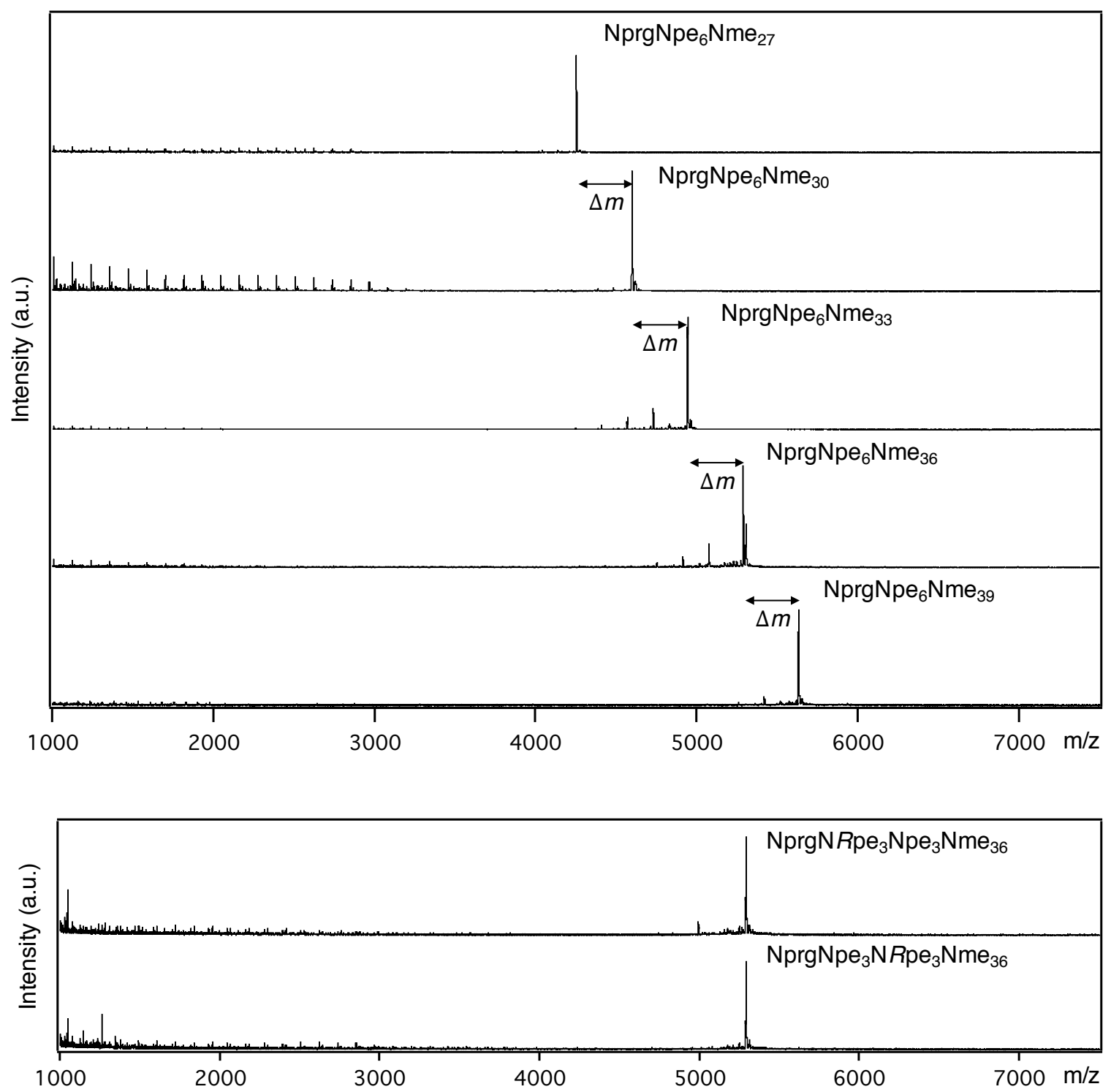

Figure S2. MALDI-TOF spectra of polypeptoids used in this study. For the $\mathrm{NprgNRpe}_{6} \mathrm{Nme}_{\mathrm{y}}$ and $\mathrm{NprgNpe}_{6} \mathrm{Nme}_{\mathrm{y}}$ series (polypeptoid naming in N-to-C direction), $\Delta m$ is $\sim 345$ between adjacent polypeptoids within the series, corresponding to the molar mass of 3 Nme units. 

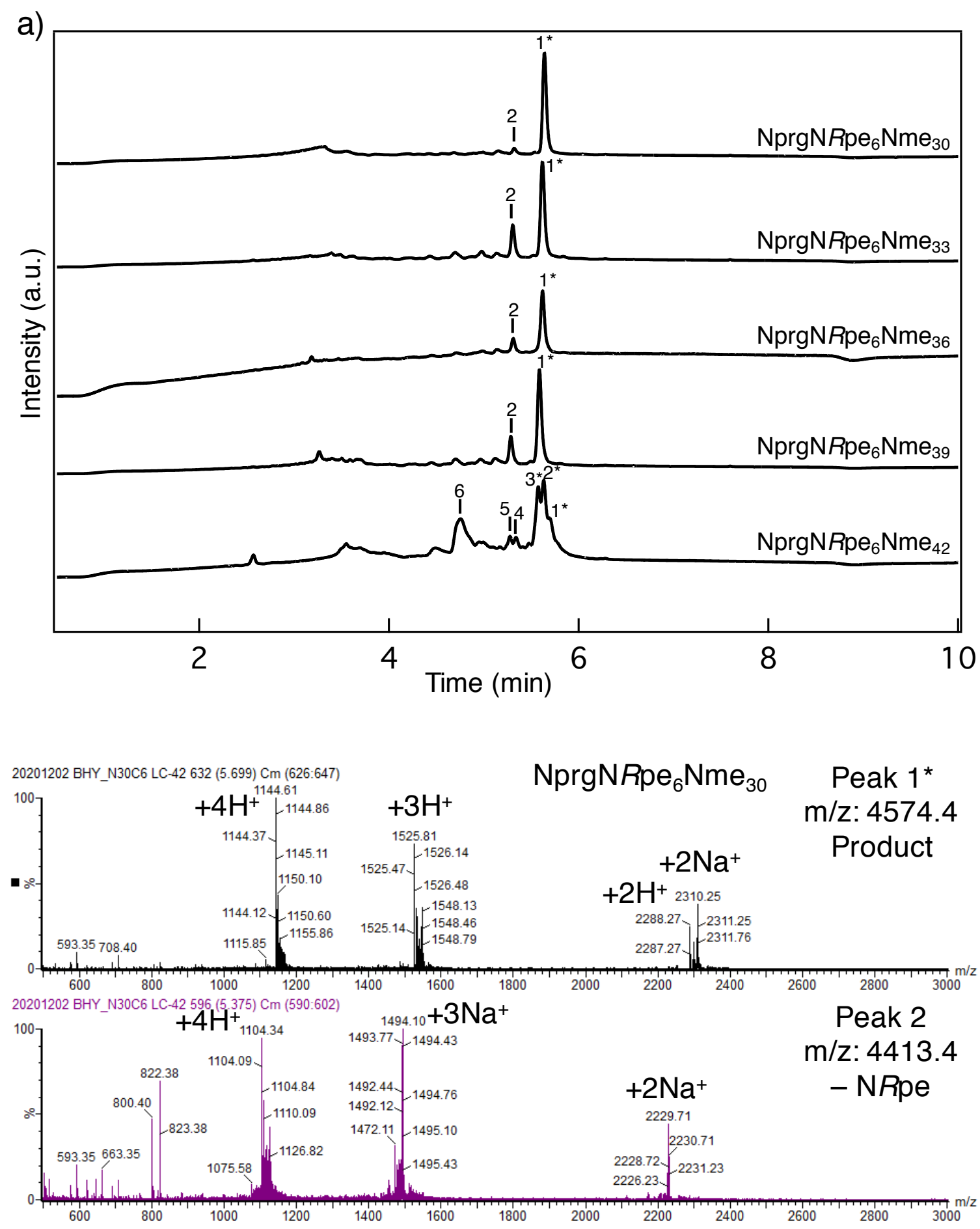

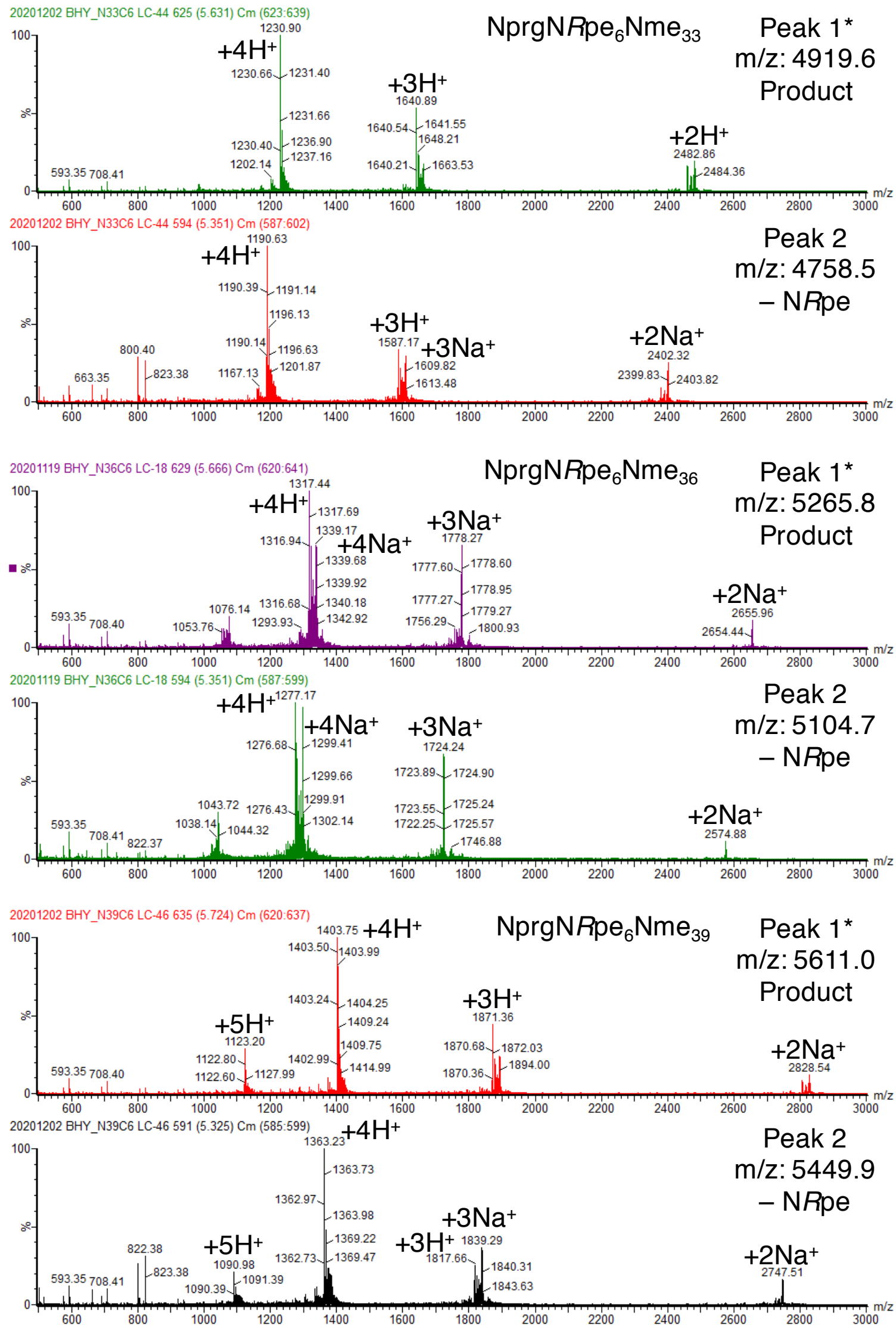
20201202 BHY_N42C6 LC-48 646 (5.819) Cm (644:654)

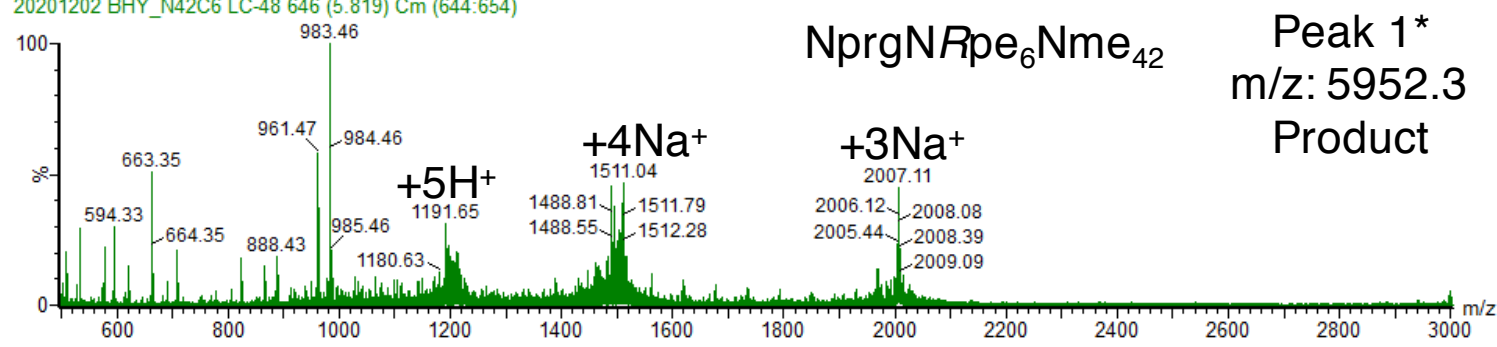

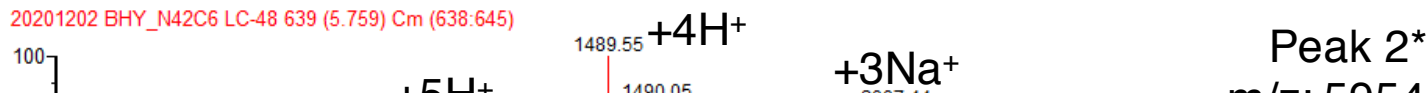

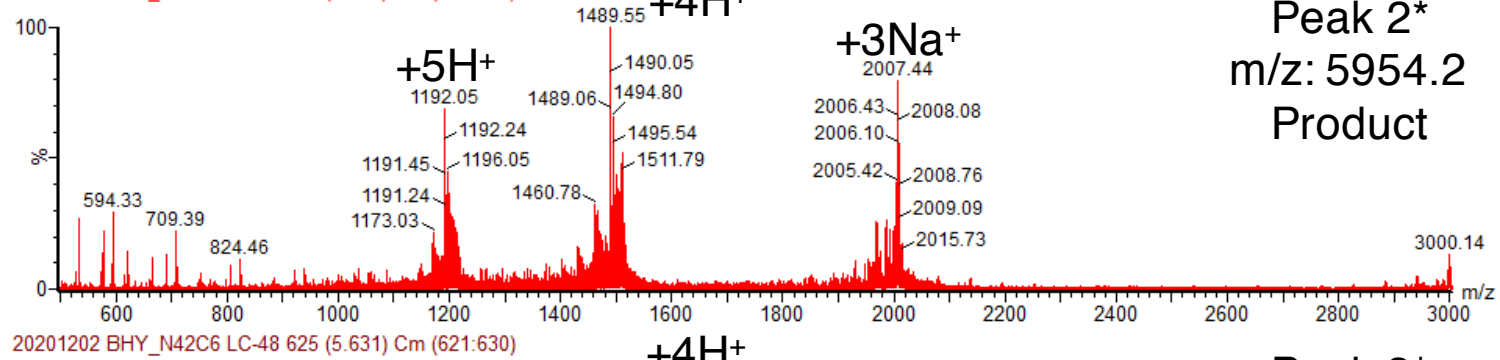

20201202 BHY_N42C6 LC-48 $625(5.631) \mathrm{Cm}(621: 630) \quad{ }_{1490.04}+\mathbf{4} \mathrm{H}^{+}$

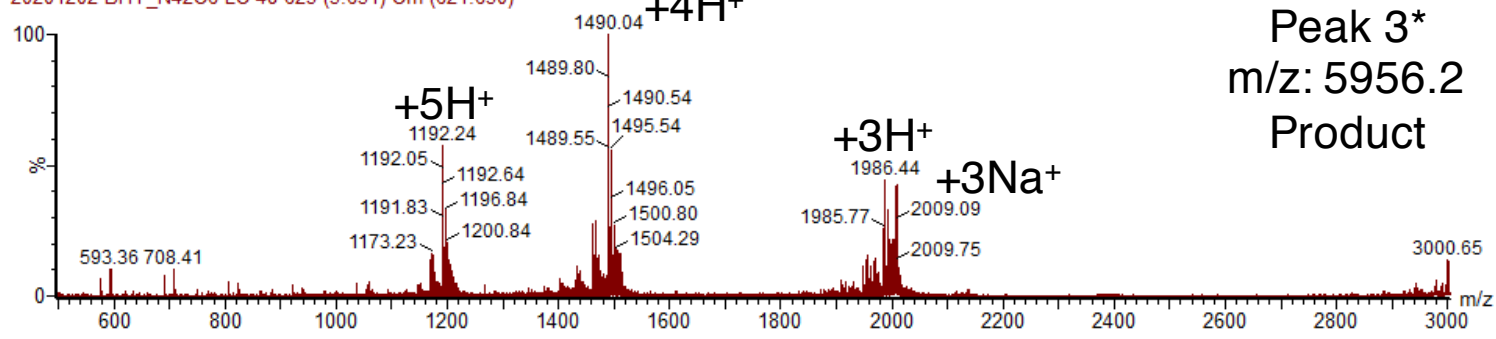

20201202 BHY_N42C6 LC-48 596 (5.375) Cm (595:603)

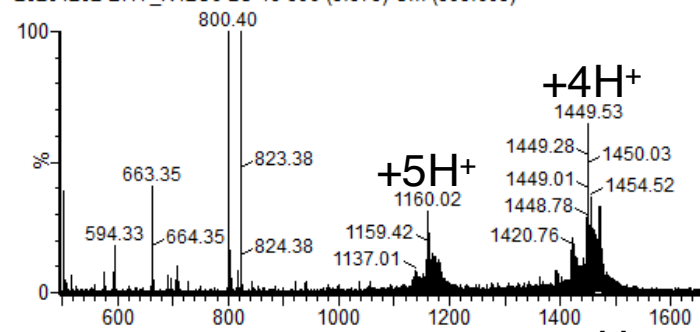

Peak 4

20201202 BHY_N42C6 LC-48 590 (5.317) Cm (587:594) $\underset{1449.76}{+4} \mathrm{H}^{+}$

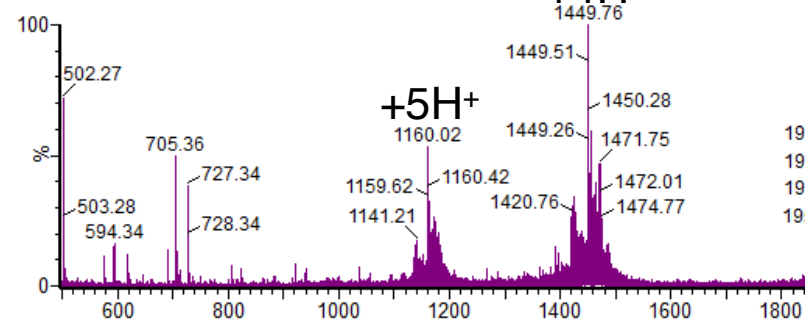

20201202 BHY_N42C6 LC-48 531 (4.789) Cm (524:549) +4 1415.52 $^{+}$
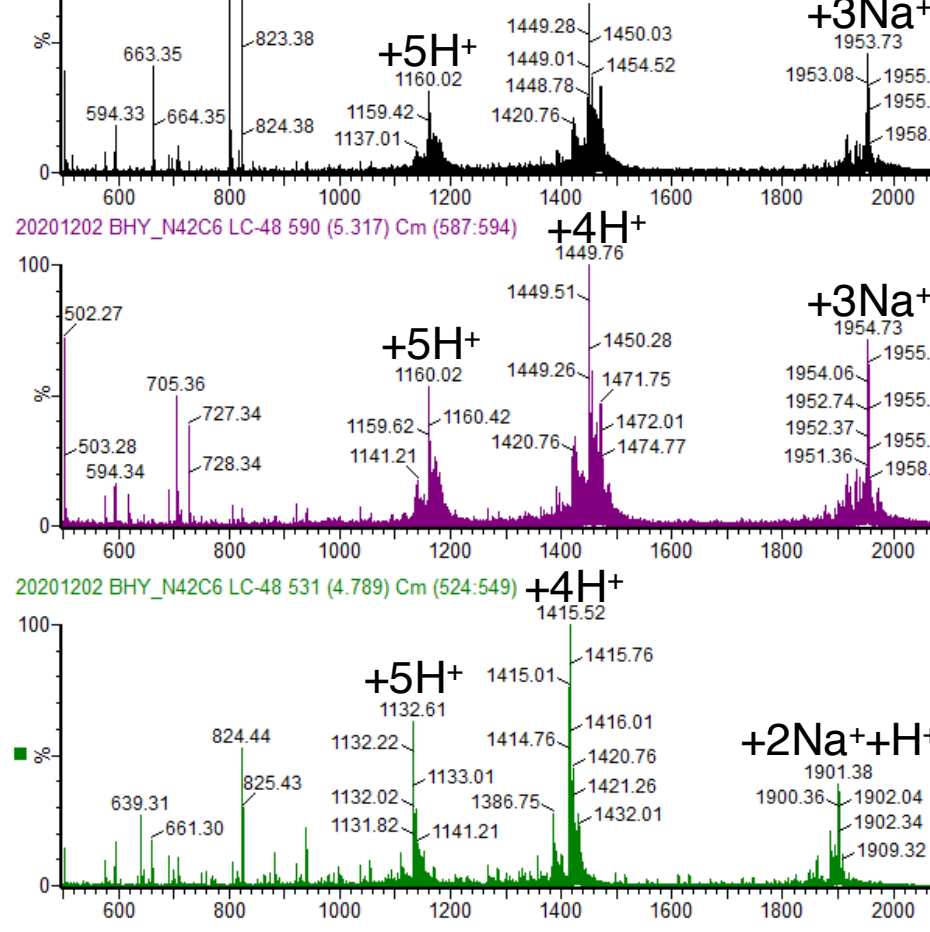

$\mathrm{m} / \mathrm{z}: 5794.1$

- NRpe 1953.08-1955.05

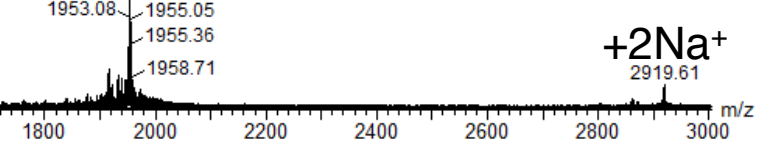

Peak 5

$\mathrm{m} / \mathrm{z}: 5795.0$

- NRpe

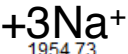

1955.05

$1952.74-1955.38$

1952.37. 1955.72

1951.36. 1958.38

$+2 \mathrm{Na}^{+}$

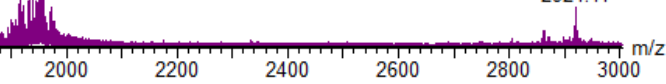

Peak 6

$\mathrm{m} / \mathrm{z}: 5658.1$

- (NRpe+Nprg+Ac)

$+2 \mathrm{Na}^{+}+\mathrm{H}^{+}$

1901.3

$1900.36+1902.04$

1909.32

$+\mathrm{Na}^{+}+\mathrm{H}^{+}$ 

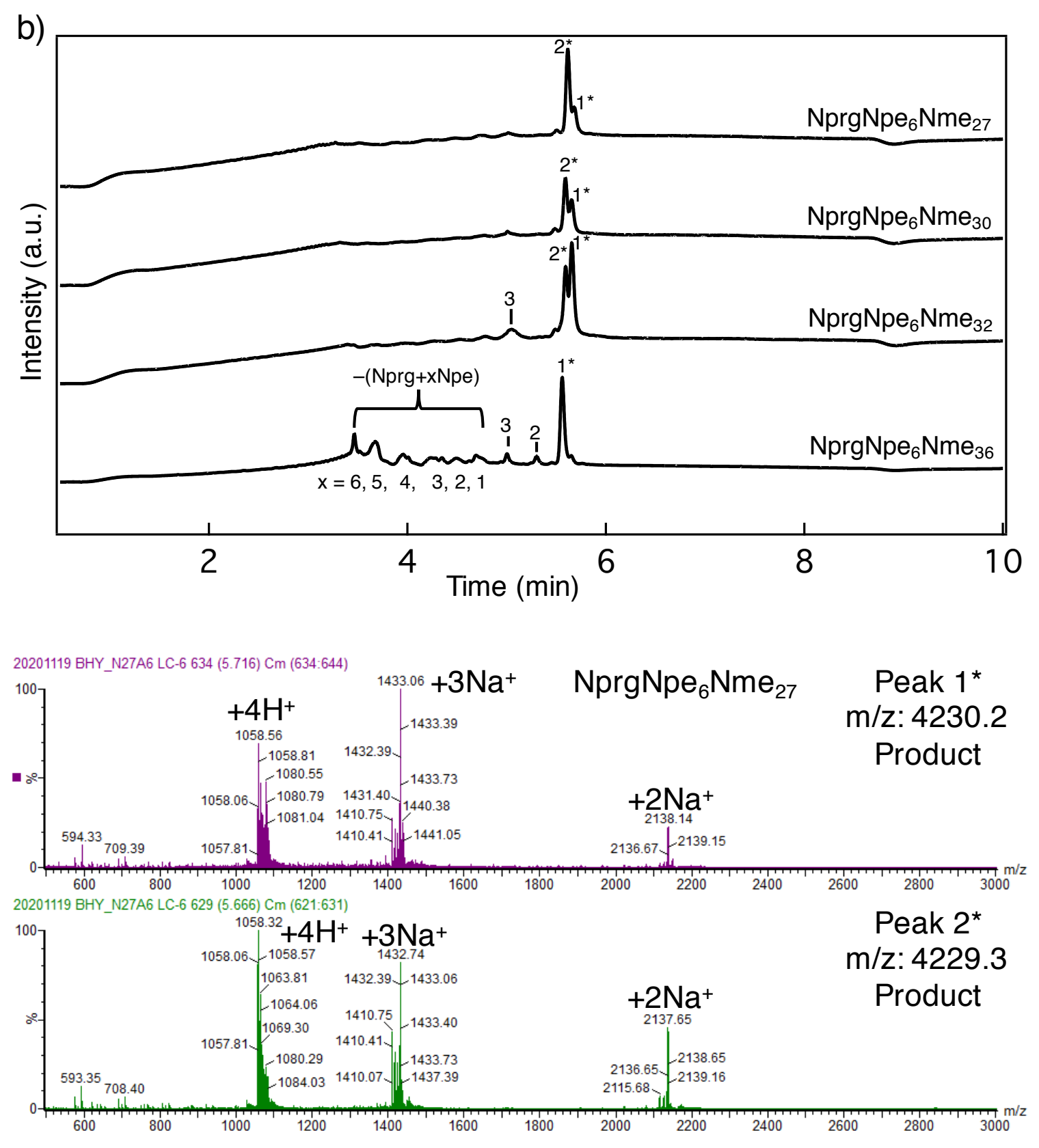

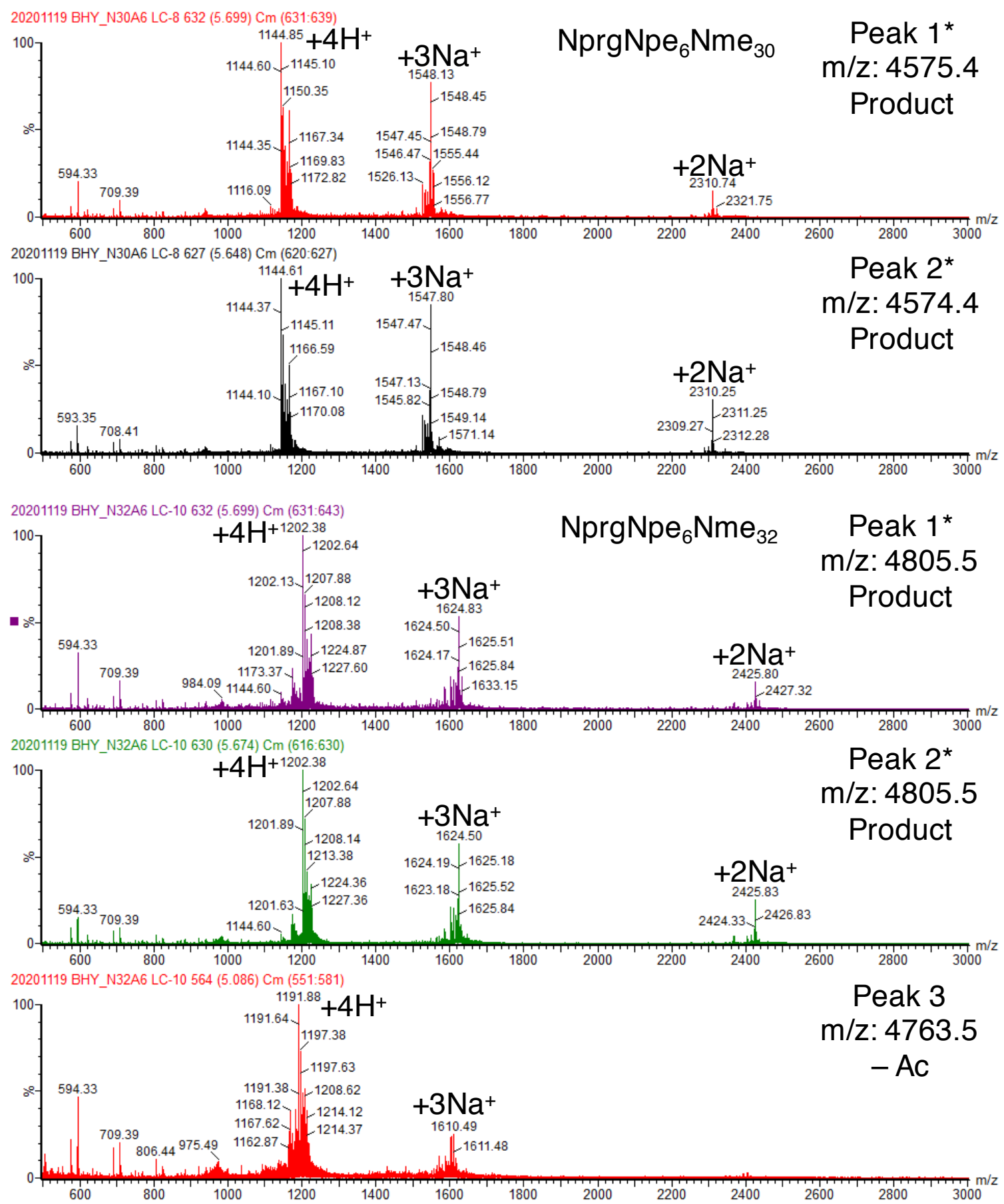

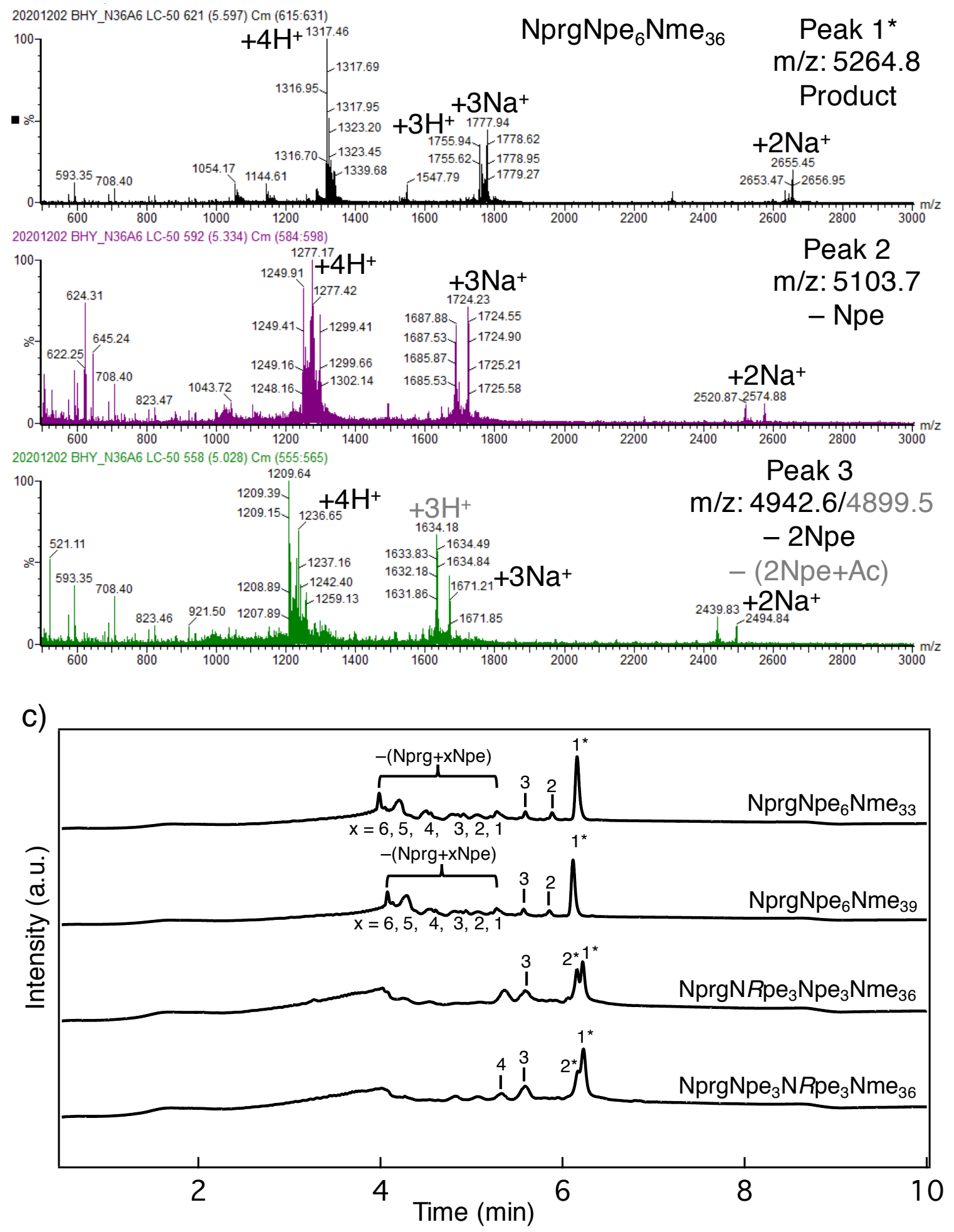

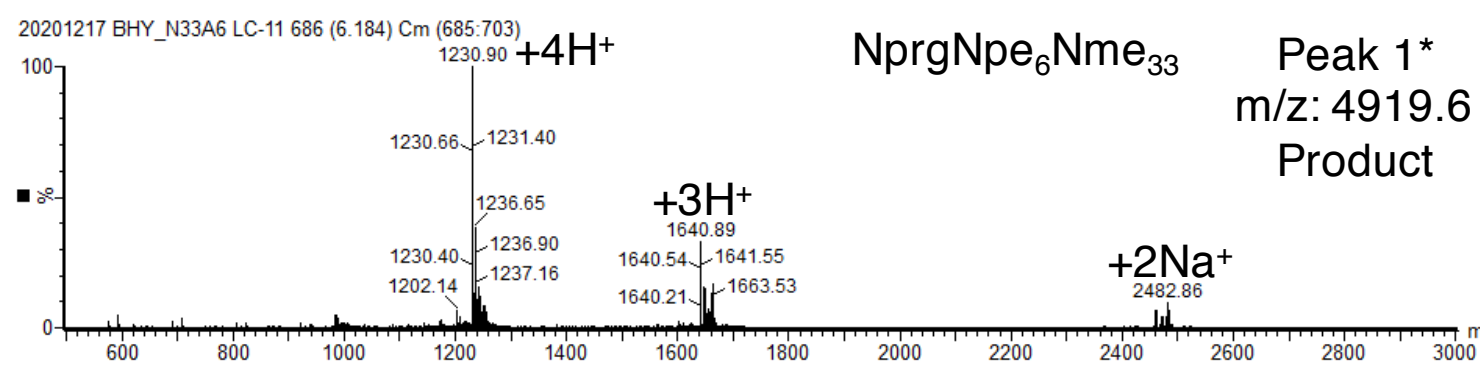

20201217 BHY_N33A6 LC-11 658 (5.929) Cm (653:667)

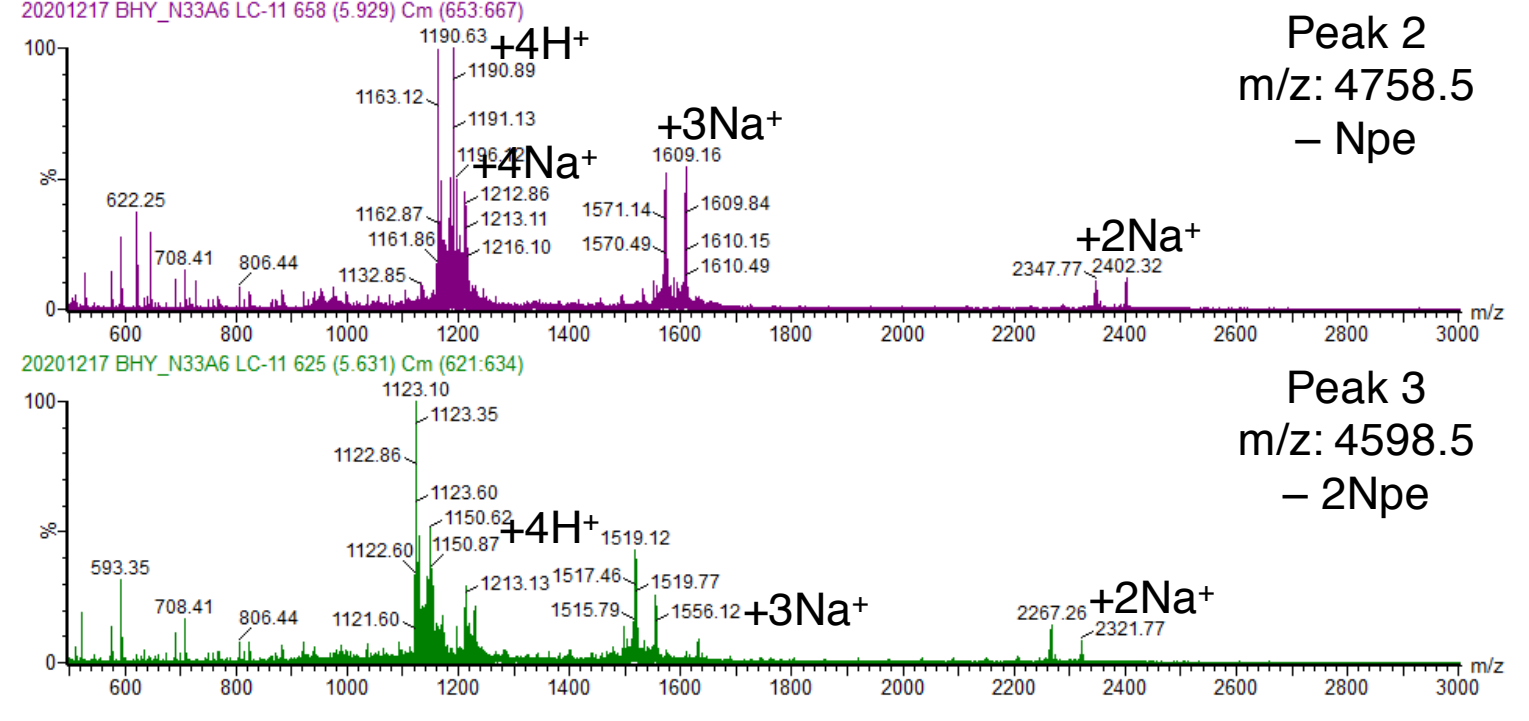

20201217 BHY_N39A6 LC-13 686 (6.184) Cm (677:697)

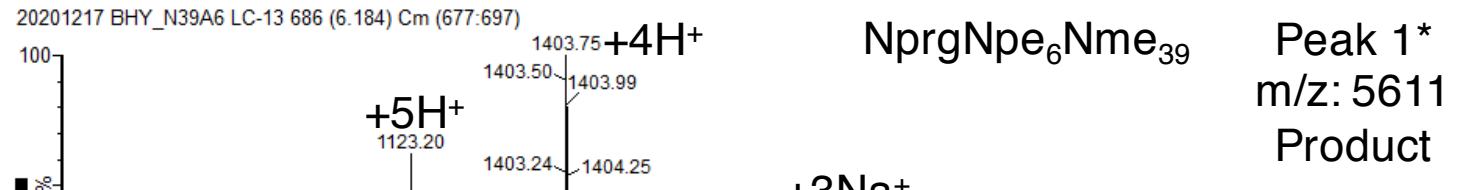
$+3 \mathrm{H}^{+}$Product 1640.54. $1641.55+2 \mathrm{Na}^{+}$
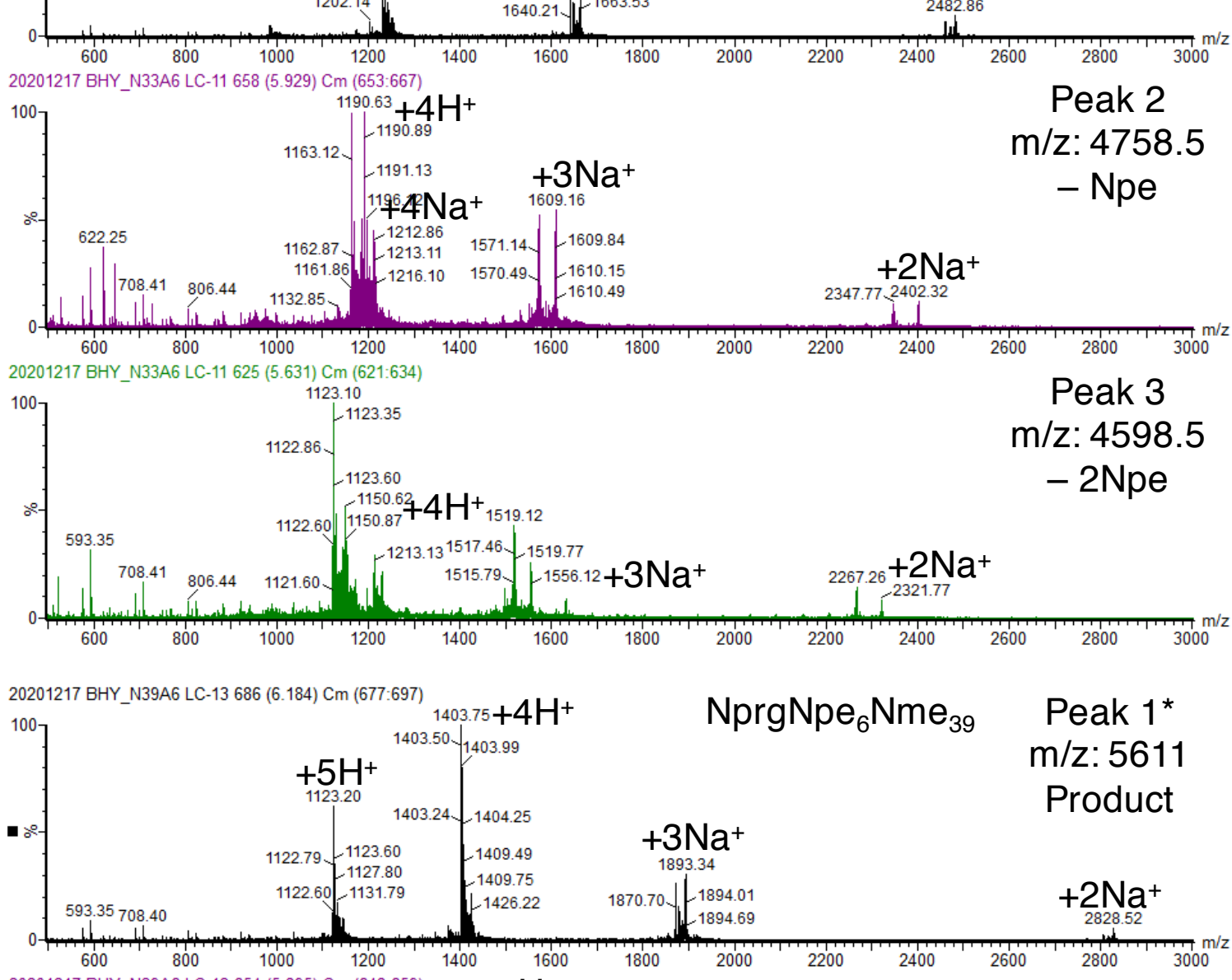

20201217 BHY_N39A6 LC-13 654 (5.895) Cm (648:659) ${ }_{1363.47}+4 \mathrm{H}^{+}$

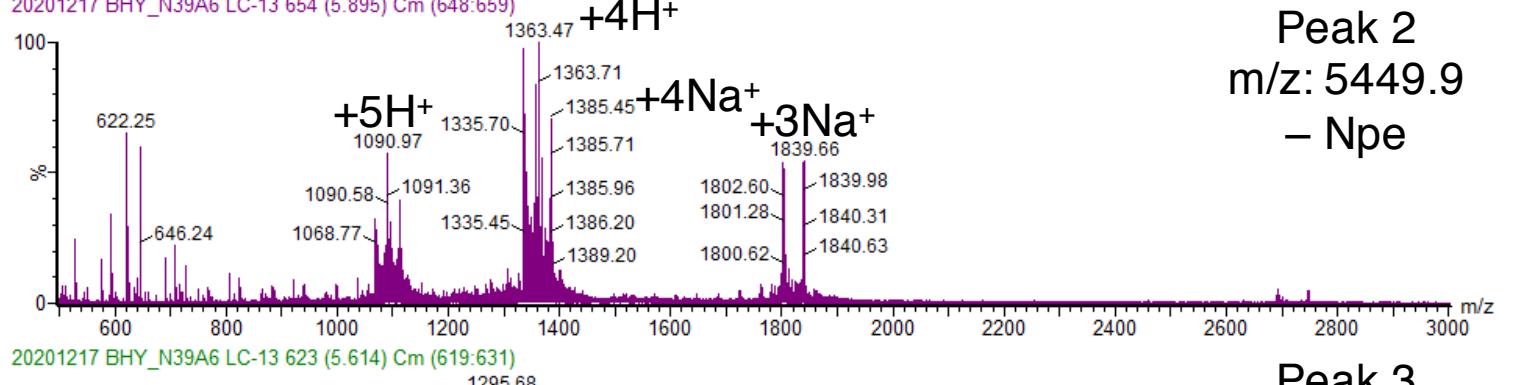

20201217 BHY_N39A6 LC-13 $623(5.614) \mathrm{Cm}(619: 631)$

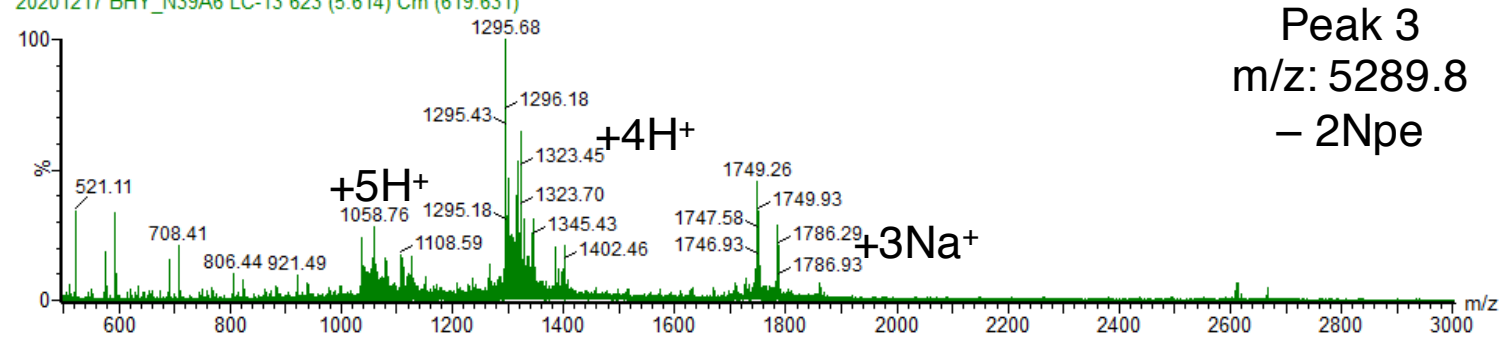




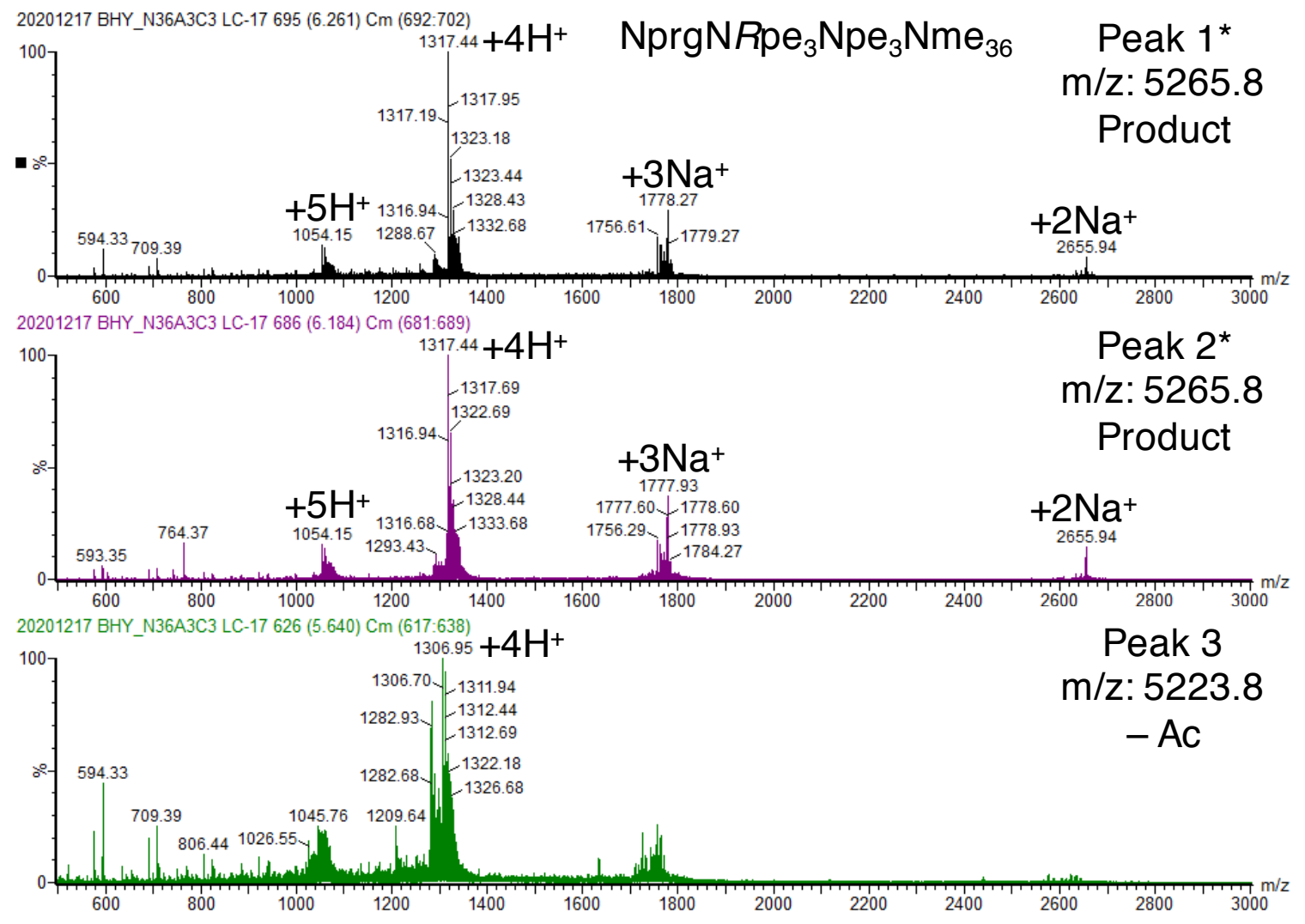




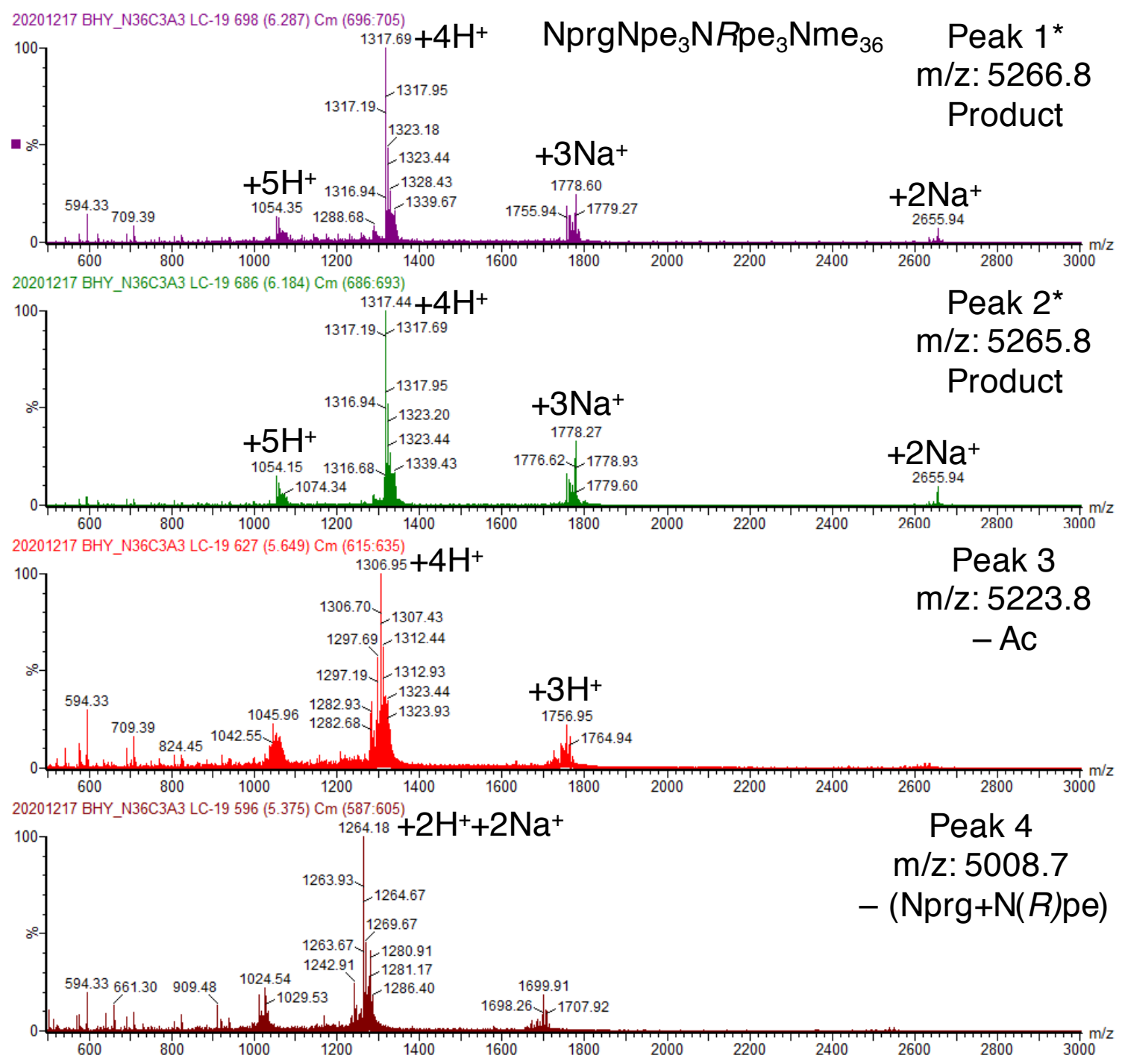

Figure S3 LC traces and MS spectra of a) the $\mathrm{NprgNRpe}_{6} \mathrm{Nme}_{\mathrm{y}}$ series polypeptoids, b) the $\mathrm{NprgNpe}_{6} \mathrm{Nme}_{\mathrm{y}}$ series polypeptoids, c) the NprgNpe ${ }_{6} \mathrm{Nme}_{\mathrm{y}}$ series polypeptoids, $\mathrm{NprgNpe}_{3} \mathrm{NRpe}_{3} \mathrm{Nme}_{36}$, $\mathrm{NprgNpe}_{3} \mathrm{NRpe}_{3} \mathrm{Nme}_{36}$. Polypeptoid species were detected by UV absorption at $214 \mathrm{~nm}$. The main product peaks are indicated with a “*”. Corresponding MS spectra for each labeled peak are shown after the LC traces, where doubly, triply, quadruply, (quintuply) charged polypeptoid species were detected in the mass spectrometer. Theoretical molar masses $(\mathrm{m} / \mathrm{z})$ of the polypeptoids: NprgNpe ${ }_{6} \mathrm{Nme}_{27}: 4229.3$ (100.0\%), 4228.3 (92.0\%), 4230.3 (50.1\%), ...; NprgNRpe ${ }_{6} \mathrm{Nme}_{30}$ and $\mathrm{NprgNpe}_{6} \mathrm{Nme}_{30}: 4574.5$ (100.0\%), 4573.5 (85.6\%), 4575.5 (58.4\%), ...; $\mathrm{NprgNpe}_{6} \mathrm{Nme}_{32}$ : 4804.6 (100.0\%), 4803.6 (81.8\%), 4805.6 (81.1\%), ...; NprgNRpe ${ }_{6} \mathrm{Nme}_{33}$ and $\mathrm{NprgNpe}_{6} \mathrm{Nme}_{33}: 4919.7$ (100.0\%), 4920.7 (82.9\%), 4918.7

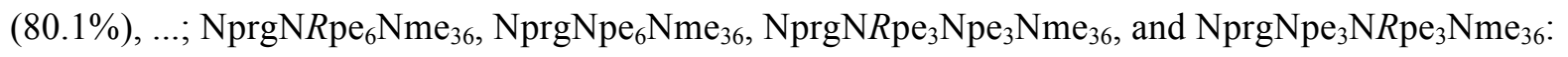
5264.9 (100.0\%), 5263.9 (75.2\%), 5265.9 (73.6\%), 5266.9 (58.0\%), ..; NprgNRpe ${ }_{6} \mathrm{Nme}_{39}$ and 
NprgNpe $_{6} \mathrm{Nme}_{39}: 5610.1$ (100.0\%), 5611.1 (93.7\%), 5609.1 (70.8\%), ..; $\mathrm{NprgNRpe}_{6} \mathrm{Nme}_{42}: 5955.2$ (100.0\%), $5956.2(87.5 \%), 5957.3(73.2 \%), 5954.2(67.0 \%), \ldots$

Notes:

- Ac refers to the $\mathrm{N}$-terminus acyl group.

- For side products that miss the Nprg unit, they do not react with the azide-terminated polystyrene in the click reaction, and will be separated from the block copolymers in the subsequent Prep GPC purification. - Polypeptoids are characterized using similar methods based on well-established methods as previously reported..$^{1-7}$

Table S1. Theoretical and LC-MS measured molar mass $(\mathrm{m} / \mathrm{z})$ of polypeptoids used in this study.

\begin{tabular}{ccc}
\hline Polypeptoids & Theoretical (m/z) & Measured (m/z) \\
\hline NprgNRpe $_{6} \mathrm{Nme}_{30}$ & 4574.5 & 4574.4 \\
NprgNRpe $_{6} \mathrm{Nme}_{33}$ & 4919.7 & 4919.6 \\
NprgNRpe $_{6} \mathrm{Nme}_{36}$ & 5264.9 & 5265.8 \\
NprgNRpe $_{6} \mathrm{Nme}_{39}$ & 5610.1 & 5611.0 \\
NprgNRpe $_{6} \mathrm{Nme}_{42}$ & 5955.2 & $5954.2 / 5956.2$ \\
\hline NprgNpe $_{6} \mathrm{Nme}_{27}$ & 4229.3 & 4229.3 \\
NprgNpe $_{6} \mathrm{Nme}_{30}$ & 4574.5 & 4574.4 \\
NprgNpe $_{6} \mathrm{Nme}_{32}$ & 4804.6 & 4805.5 \\
NprgNpe $_{6} \mathrm{Nme}_{33}$ & 4919.7 & 4919.6 \\
NprgNpe $_{6} \mathrm{Nme}_{36}$ & 5264.9 & 5264.8 \\
NprgNpe $_{6} \mathrm{Nme}_{39}$ & 5610.1 & 5611.0 \\
\hline NprgNRpe $_{3} \mathrm{Npe}_{3} \mathrm{Nme}_{27}$ & 5264.9 & 5265.8 \\
NprgNpe $_{3} \mathrm{~N} R e_{3} \mathrm{Nme}_{27}$ & 5264.9 & 5265.8 \\
\hline
\end{tabular}




\section{Polystyrene Characterization}

Table S2. Summary of conversion/yields of polystyrenes used in this study

ATRP synthesis conversion (PS-Br)

\begin{tabular}{|c|c|c|c|}
\hline & $\begin{array}{c}M_{n} \text { measured by GPC } \\
\left(\mathrm{g} \mathrm{mol}^{-1}\right)\end{array}$ & Yield (g) & Conversion \\
\hline $4-95 \mathrm{~A}$ & 10200 & 3.3460 & $66.9 \%$ \\
\hline $4-124 B$ & 10300 & 3.7601 & $75.2 \%$ \\
\hline $4-140 \mathrm{~B}$ & 11000 & 4.0773 & $81.5 \%$ \\
\hline \multicolumn{4}{|c|}{ Azide-substitution conversion } \\
\hline & $\begin{array}{c}M_{n} \text { measured by GPC } \\
\left(\mathrm{g} \mathrm{mol}^{-1}\right)\end{array}$ & $\operatorname{PS}-\mathrm{Br}(\mathrm{g})$ & Recovered PS-N $\mathrm{N}_{3}(\mathrm{~g})$ \\
\hline $4-95 \mathrm{~A}$ & 10200 & 3.0 & 2.5306 \\
\hline $4-124 \mathrm{~B}$ & 10300 & 3.5 & 3.2034 \\
\hline $4-140 \mathrm{~B}$ & 11000 & 3.8 & 3.4792 \\
\hline
\end{tabular}

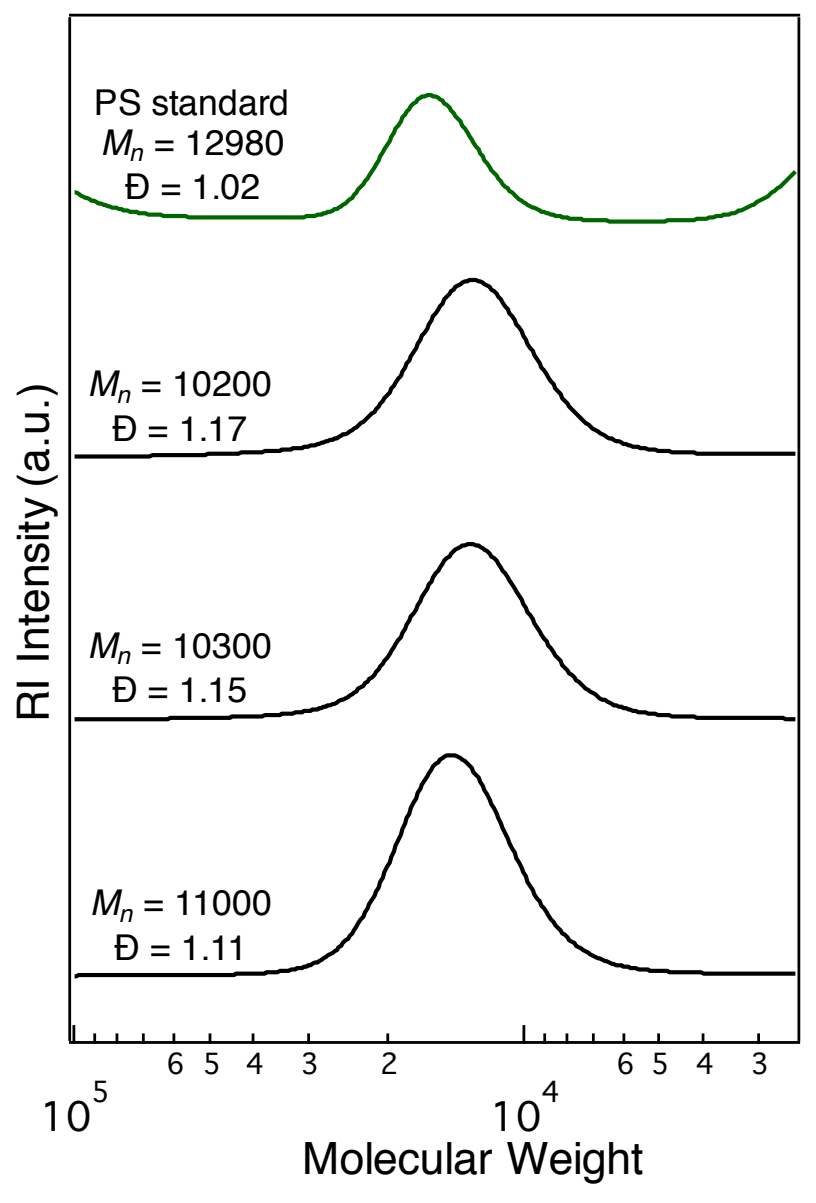

Figure S4. THF GPC traces of polystyrenes used in this study, with molecular weight calibrated against polystyrene standards. 


\section{Block Copolymer Characterization}

Copper was removed by passing the click reaction mixture through a basic alumina column. The filtered solutions and the final products were colorless, which indicate successful removal of copper. The overall purification procedure of block copolymers consists of two purification steps to remove polystyrene and polypeptoid homopolymers respectively: 1) The crude product from click reactions was first precipitated into a hexane : cyclohexane mixture to remove excess polystyrene; 2) The product from precipitation was further purified via Prep GPC. For each block copolymer, fractions were collected with 30 s intervals, then characterized with MALDI to determine which fractions to combine (Figure S5). Only prep GPC fractions that were free of polypeptoids are combined and used as the final block copolymer materials with no identifiable peptoid fraction remaining (Figure S6).

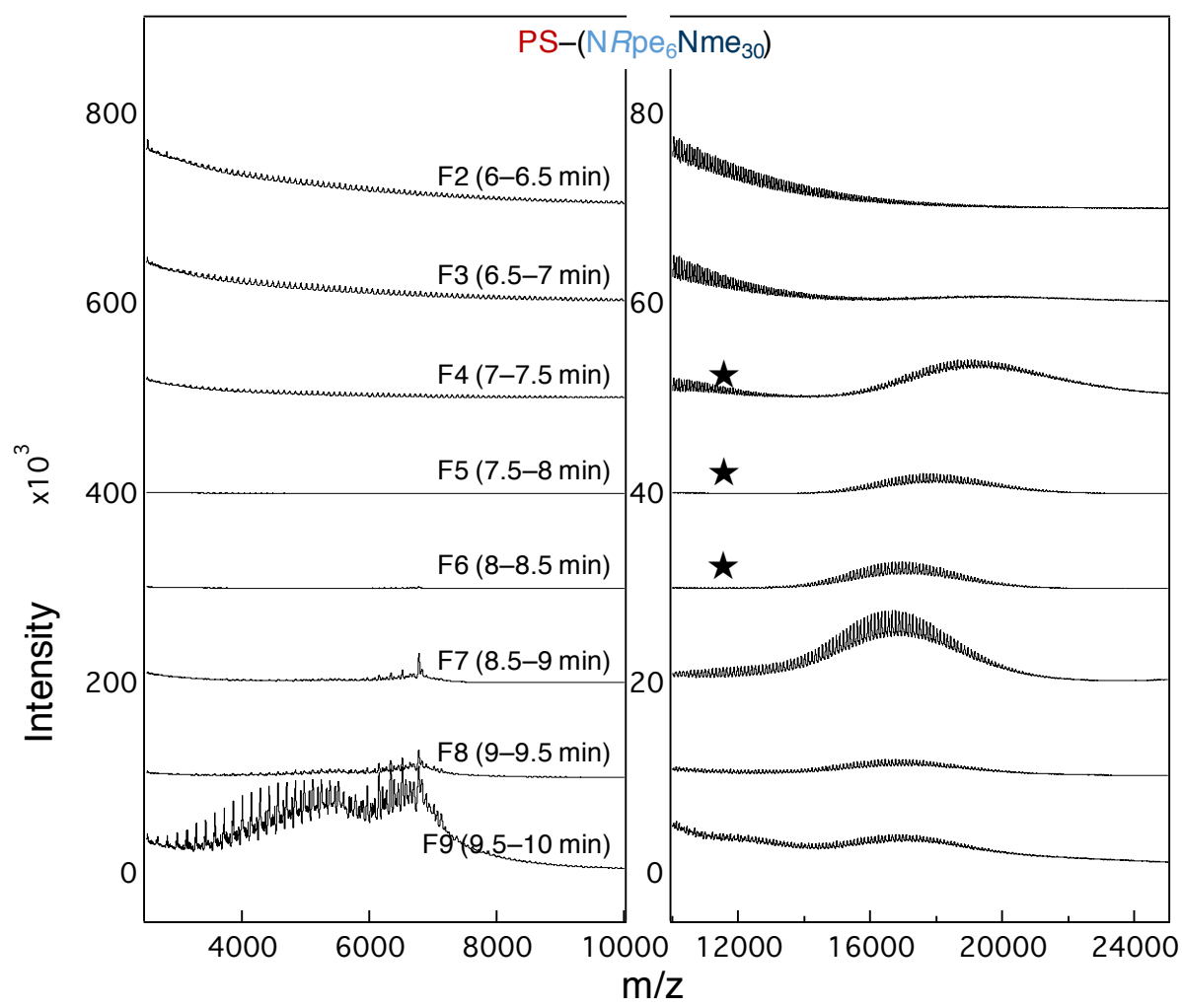



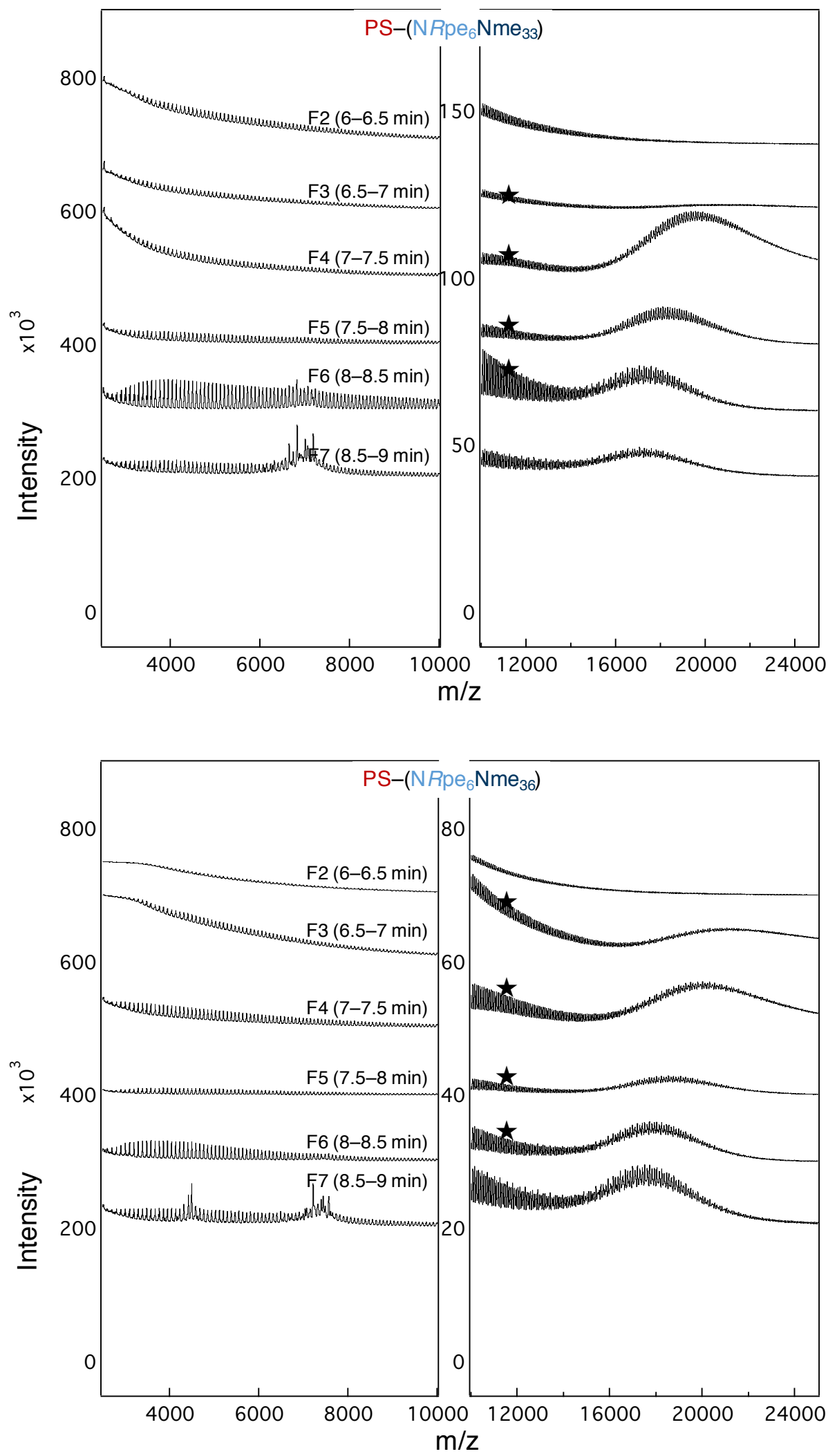

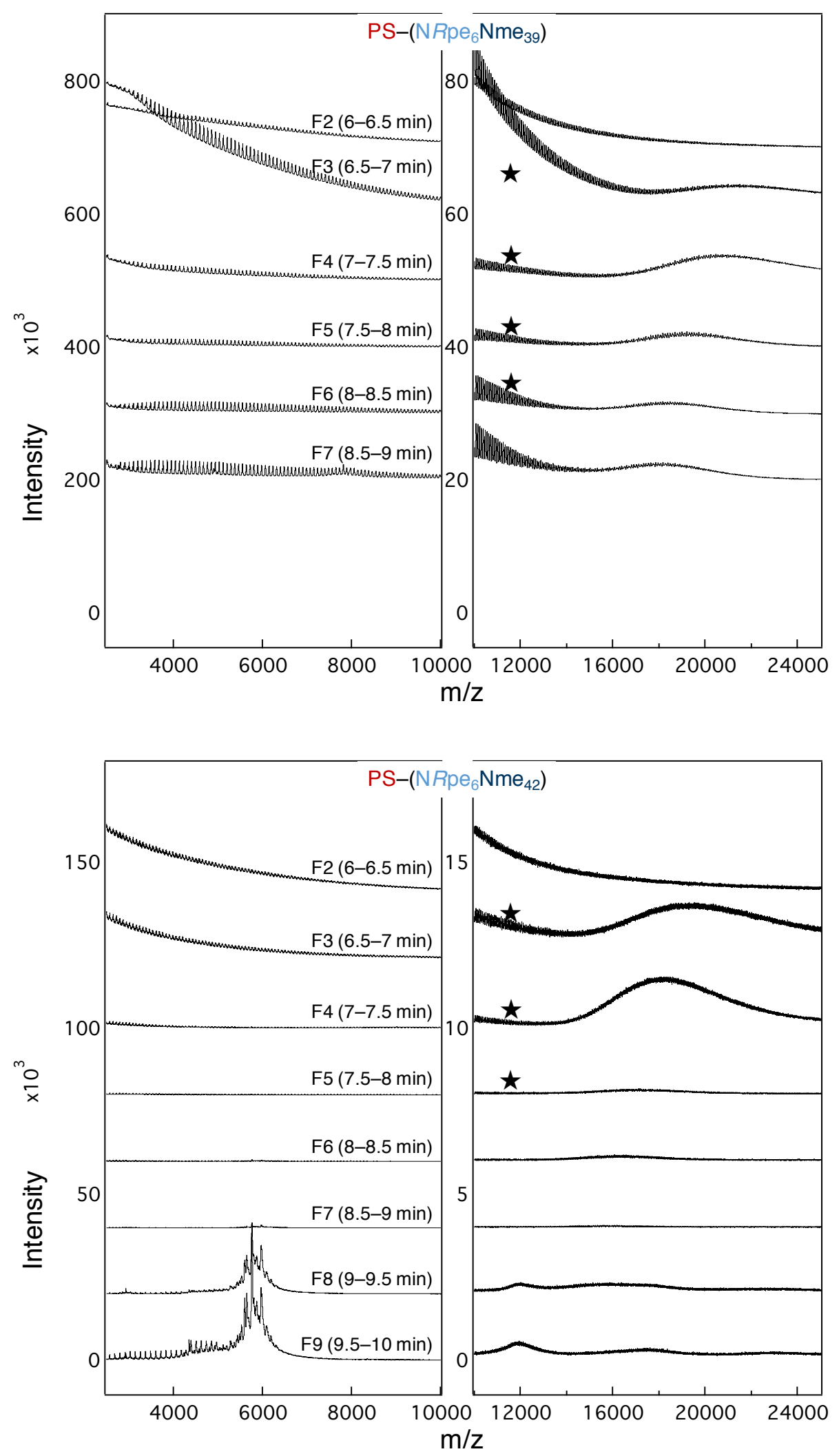

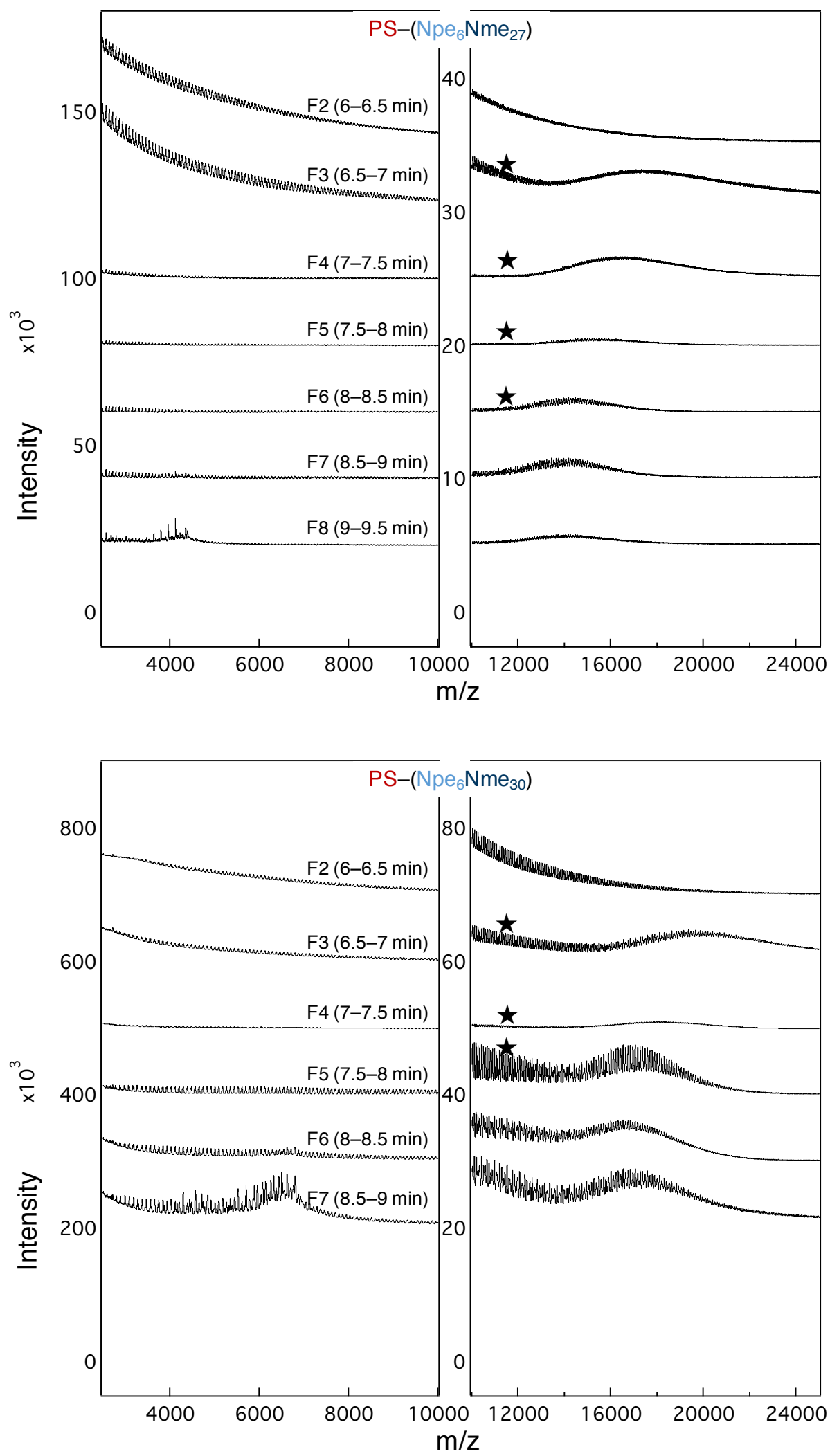

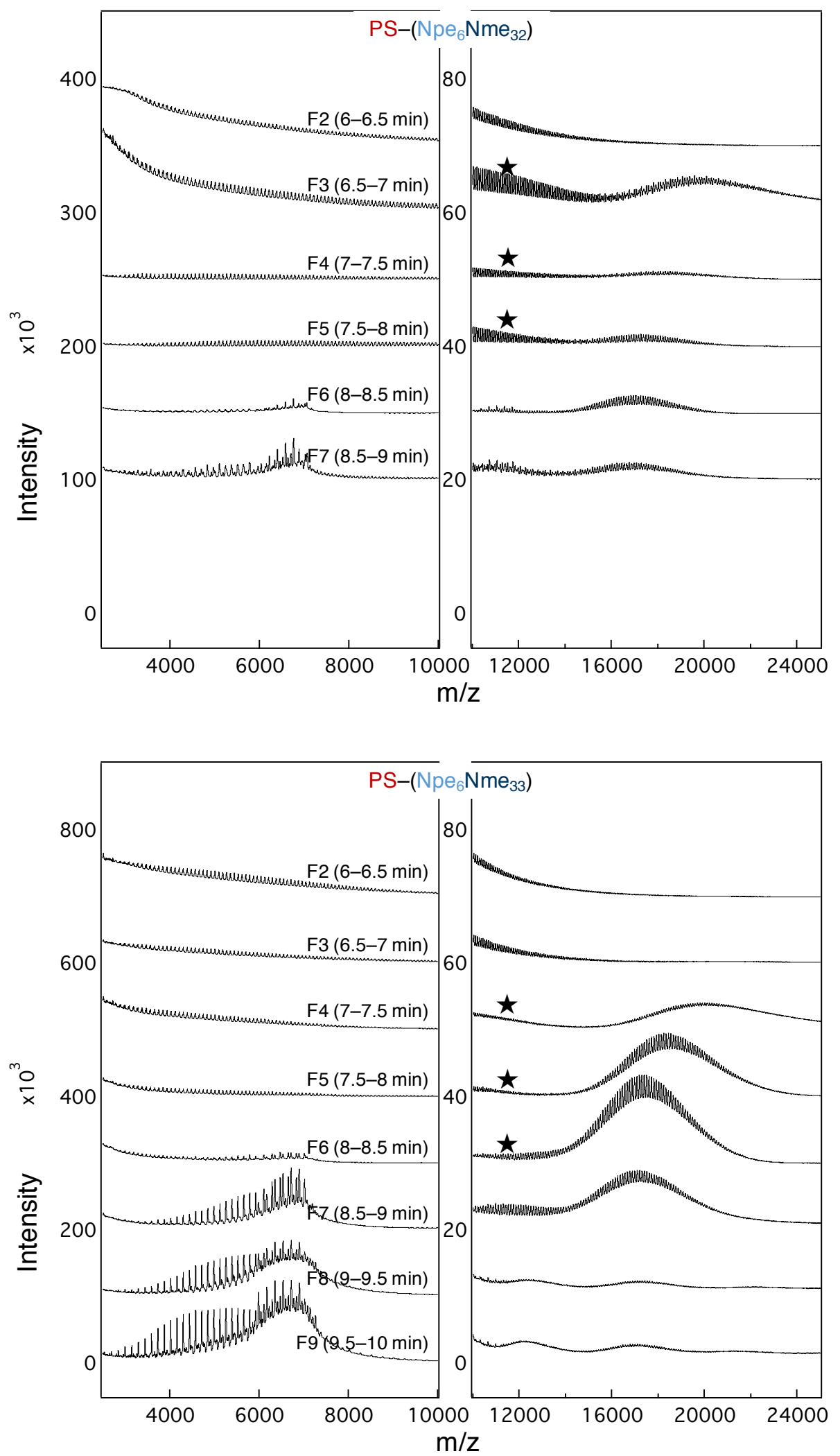

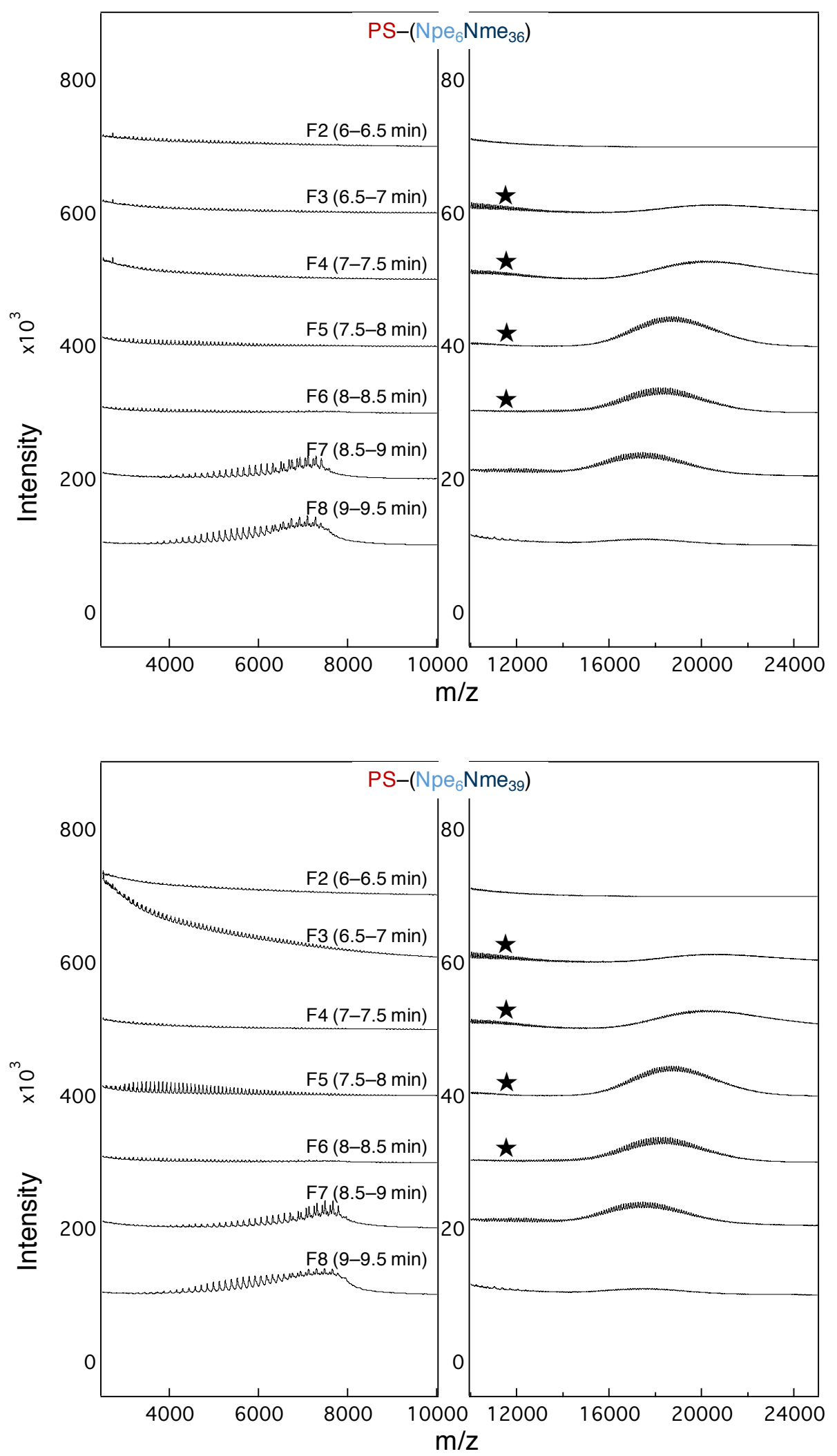

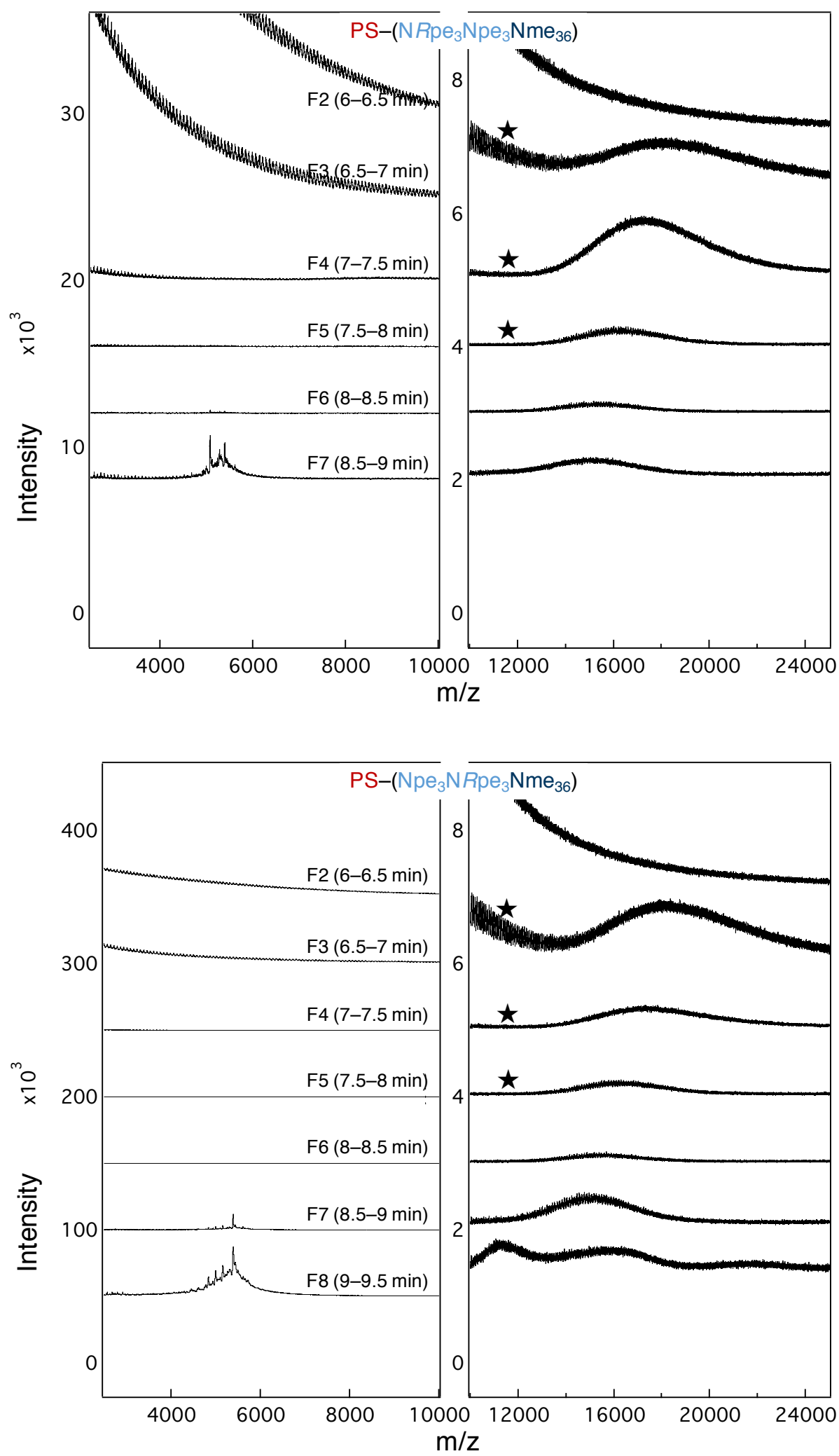

Figure S5. MALDI spectra of collected Prep GPC fractions of the PS- $\left(\mathrm{N} R \mathrm{pe}_{6} \mathrm{Nme}_{\mathrm{y}}\right), \mathrm{PS}-\left(\mathrm{Npe}_{6} \mathrm{Nme}_{\mathrm{y}}\right)$, and PS-(NRpe $\left.{ }_{3} \mathrm{Npe}_{3} \mathrm{Nme}_{36}\right)$, PS- $\left(\mathrm{Npe}_{3} \mathrm{NRpe}{ }_{3} \mathrm{Nme}_{36}\right)$. Polypeptoids in the collected fractions are much 
easier to ionize and produce much higher intensities than the block copolymers. Therefore, the $\mathrm{m} / \mathrm{z}$ axis was presented in two ranges (2500-10000 and 10000-25000) with different intensity scales for the purpose of displaying block copolymers. Fractions labelled with $\star$ are combined and used for subsequent SAXS characterization.

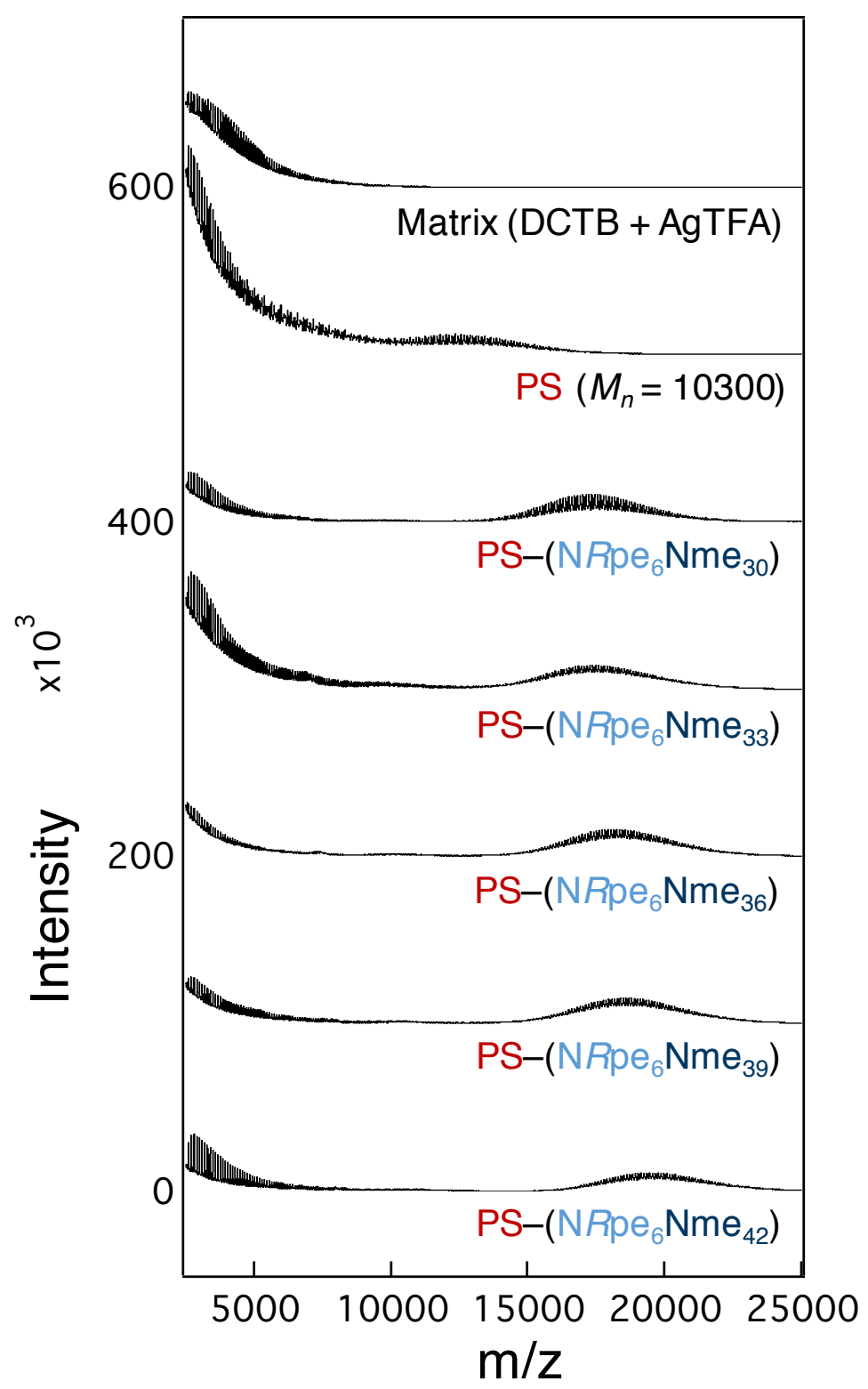




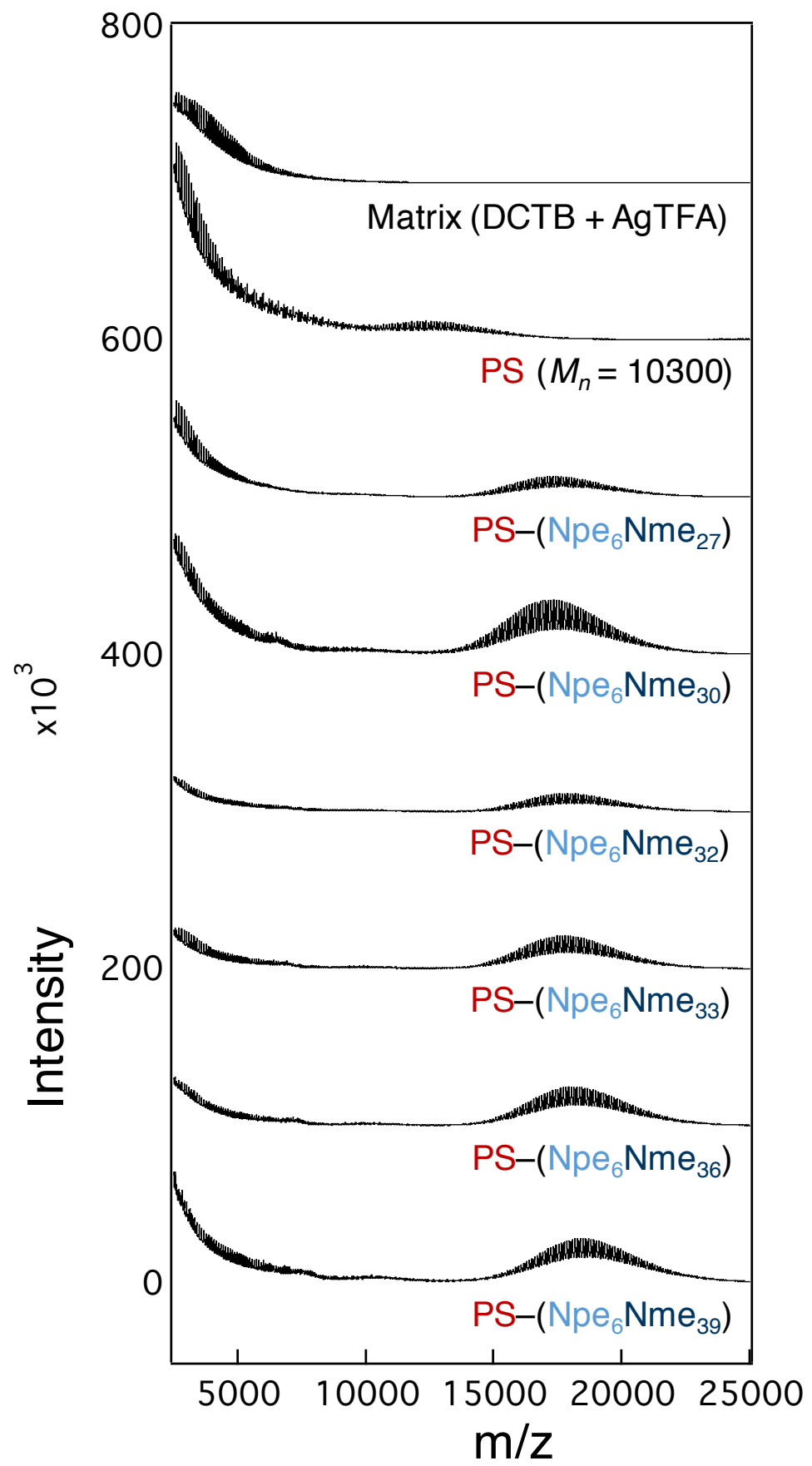




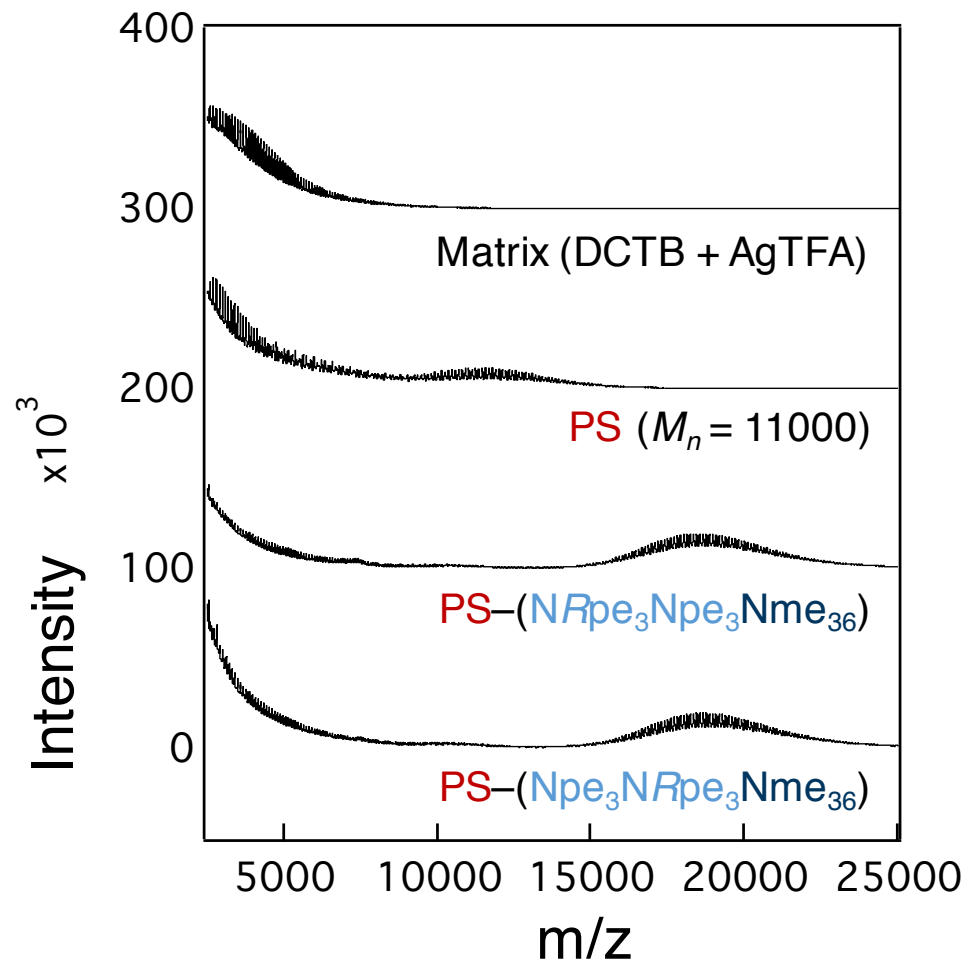

Figure S6. MALDI spectra of final block copolymers used for SAXS characterization. No obvious polystyrene or polypeptoid homopolymers were observed. 

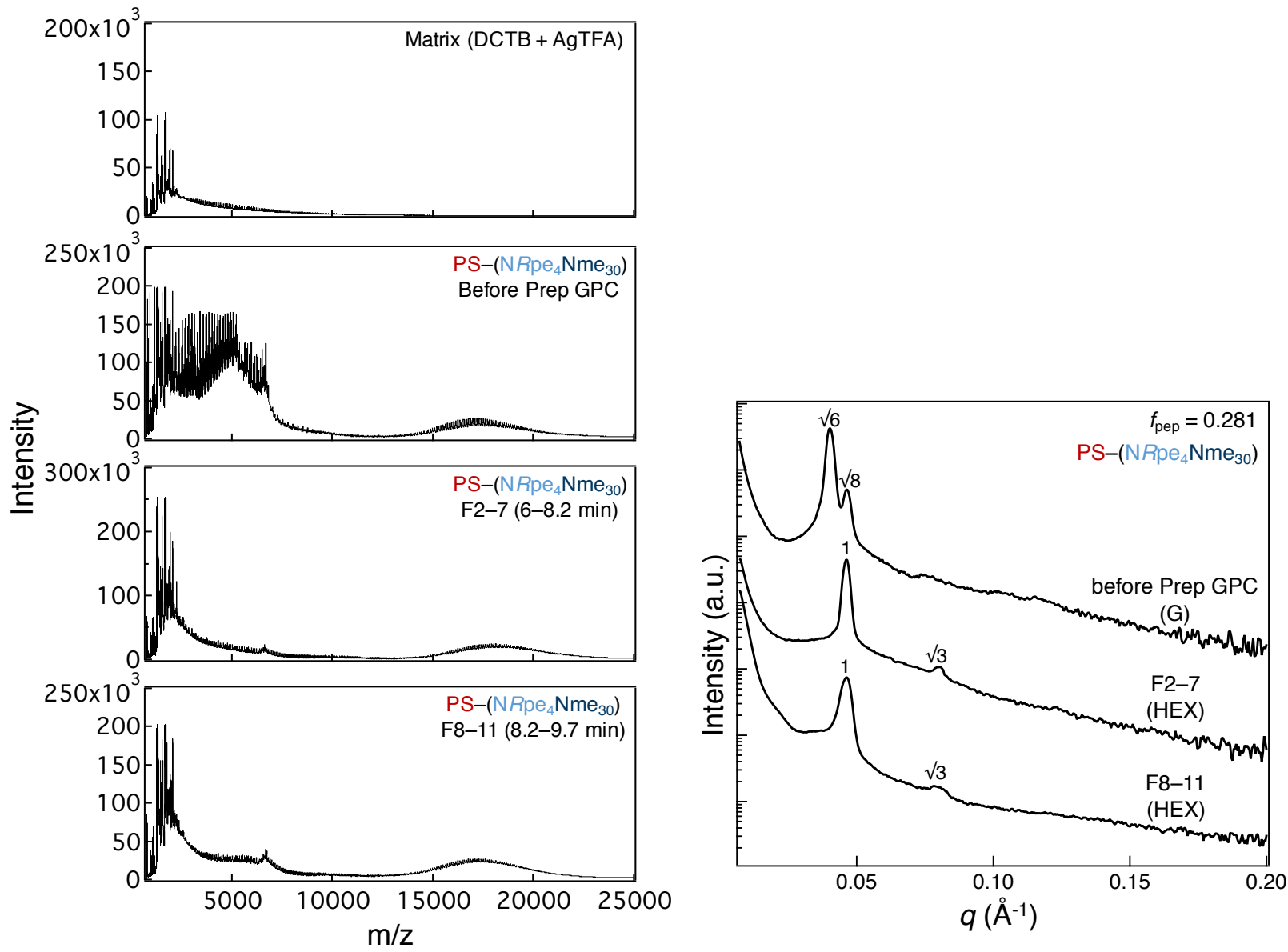

Figure S7. An example of block copolymer PS-(NRpe $\left.{ }_{4} \mathrm{Nme}_{30}\right)$ with polypeptoid volume fraction $f_{\text {pep }}=$ 0.281. The product before Prep GPC purification has a large amount of low molecular weight impurities as indicated by MALDI and it adopts a double gyroid morphology. The collected Prep GPC fractions have negligible impurities/polypeptoids and adopt a cylindrical morphology. This indicates removing the low molecular weight impurities is critical to obtain the actual morphology adopted by the neat block copolymers. 


\section{SAXS Characterization}

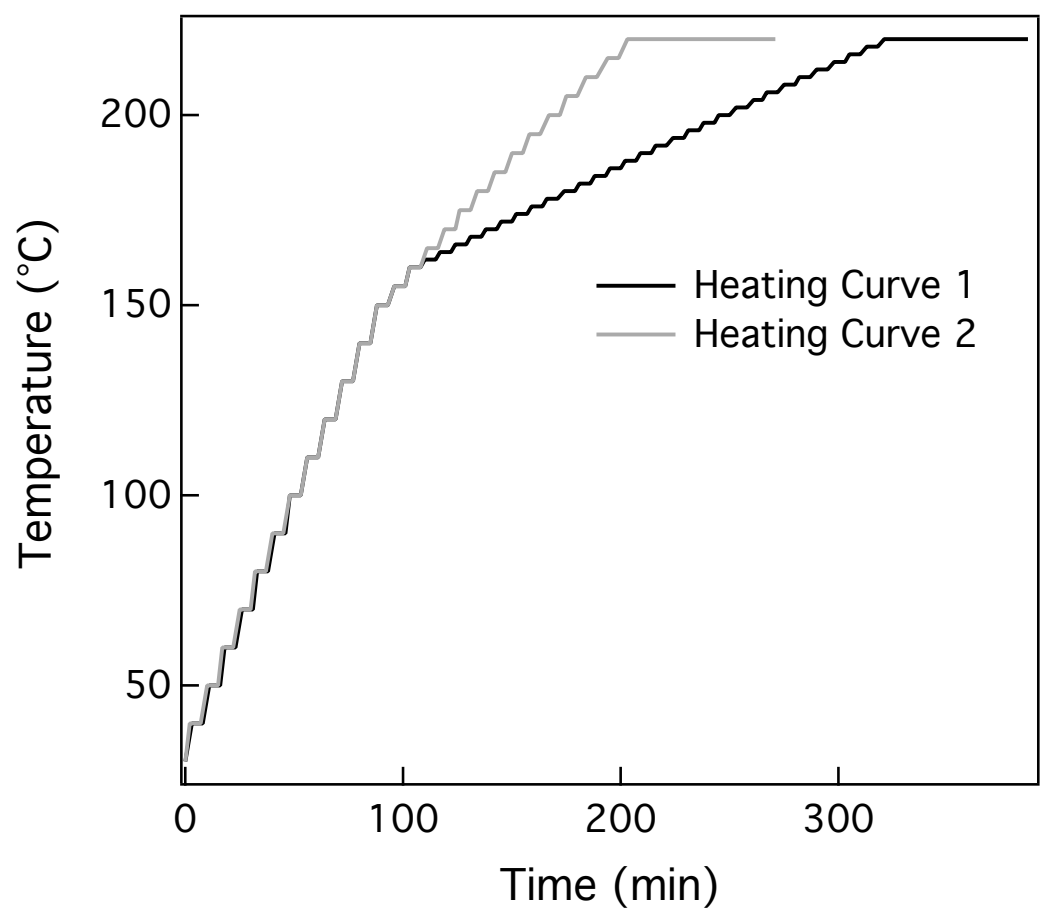

Figure S8. Temperature profiles as a function of time for the in-situ temperature SAXS studies. Before exposure at each temperature, samples are equilibrated for $5 \mathrm{~min}$ as indicated by the short plateaus. Heating curve 1 was used for PS-(NRpe $\left.{ }_{6} \mathrm{Nme}_{36}\right)$, PS-(NRpe $\left.{ }_{6} \mathrm{Nme}_{39}\right)$, PS- $-\left(\mathrm{Npe}_{6} \mathrm{Nme}_{33}\right)$, and PS$\left(\mathrm{Npe}_{6} \mathrm{Nme}_{36}\right)$. Heating curve 2 was used for PS-(NRpe $\left.{ }_{6} \mathrm{Nme}_{42}\right)$, PS- $\left(\mathrm{Npe}_{6} \mathrm{Nme}_{32}\right)$, and PS- $\left(\mathrm{Npe}_{6} \mathrm{Nme}_{39}\right)$. 

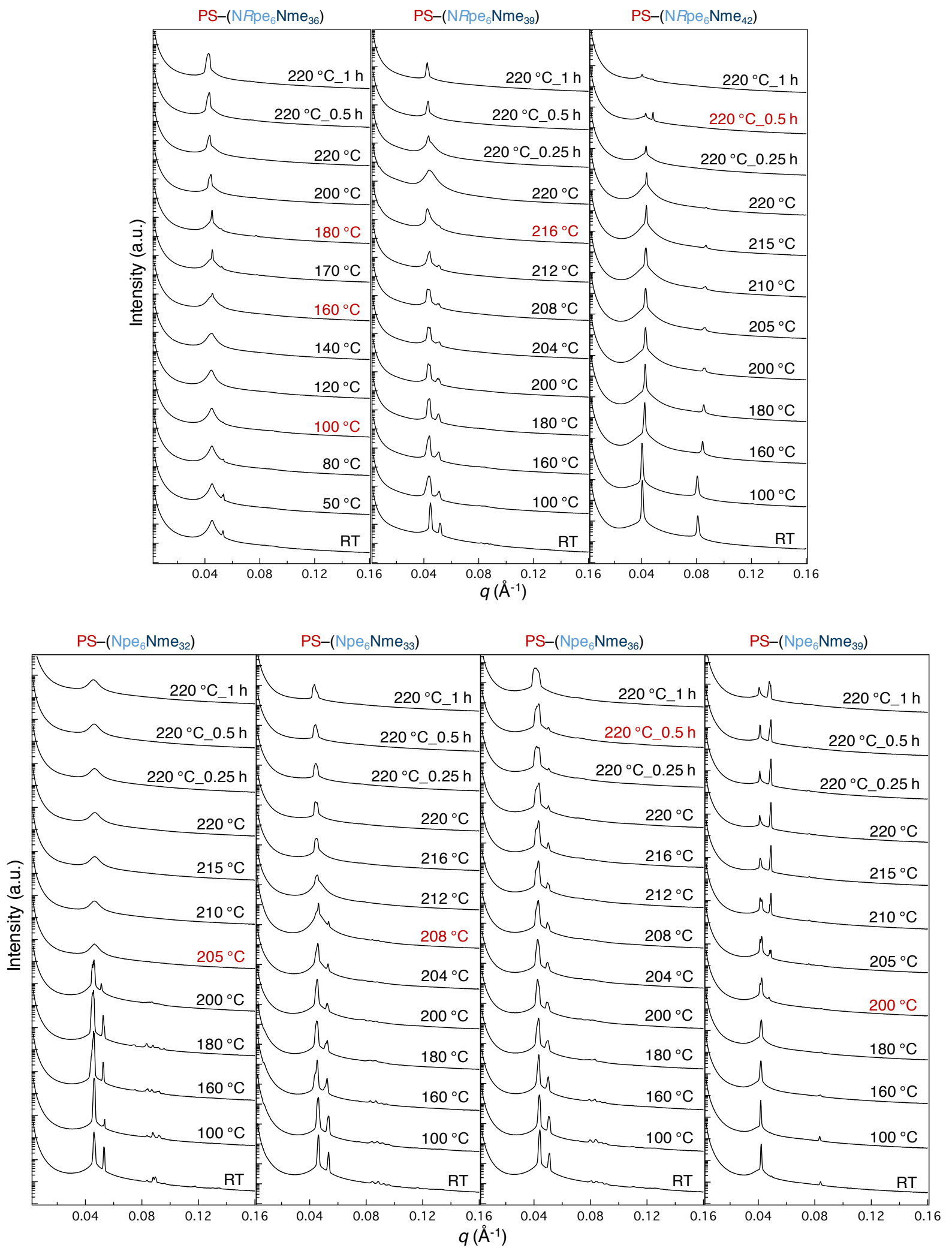

Figure S9. In-situ temperature SAXS studies. SAXS curves are presented at selected temperatures for simplicity, with transition temperatures included and highlighted in red. 


\section{Supplemental Calculations}

Table S3. Estimated purity of the polypeptoid block and recalculated $f_{\text {pep }}$ accounting for impurities.

\begin{tabular}{|c|c|c|c|c|c|c|}
\hline \multirow[t]{2}{*}{ BCP ID } & \multirow{2}{*}{$\begin{array}{c}\text { Estimated } \\
\text { purity } \\
(\%)\end{array}$} & \multicolumn{2}{|l|}{ Impurities $^{*}$} & \multirow{2}{*}{$\begin{array}{l}\text { Reported } \\
f_{\text {pep }}\end{array}$} & \multirow{2}{*}{$\begin{array}{c}\text { Recalculated } \\
f_{\text {pep accounting }} \\
\text { for impurities }\end{array}$} & \multirow[t]{2}{*}{$Đ$} \\
\hline & & Species & $\%$ & & & \\
\hline $\mathrm{PS}-\left(\mathrm{NRp \textrm {e } _ { 6 } \mathrm { Nme } _ { 3 0 } )}\right.$ & 95 & $\mathrm{PS}-\left(\mathrm{NRpe}{ }_{5} \mathrm{Nme}_{30}\right)$ & 5 & 0.285 & 0.285 & 1.00006 \\
\hline $\mathrm{PS}-\left(\mathrm{N} R \mathrm{pe}_{6} \mathrm{Nme}_{33}\right)$ & 77 & $\mathrm{PS}-\left(\mathrm{N} R \mathrm{pe}_{5} \mathrm{Nme}_{33}\right)$ & 23 & 0.298 & 0.297 & 1.00020 \\
\hline $\mathrm{PS}-\left(\mathrm{NRpe}{ }_{6} \mathrm{Nme}_{36}\right)$ & 84 & $\mathrm{PS}-\left(\mathrm{NRpe}{ }_{5} \mathrm{Nme}_{36}\right)$ & 16 & 0.313 & 0.312 & 1.00013 \\
\hline $\mathrm{PS}-\left(\mathrm{NRpe}{ }_{6} \mathrm{Nme}_{39}\right)$ & 79 & $\mathrm{PS}-\left(\mathrm{NRpe}{ }_{5} \mathrm{Nme}_{39}\right)$ & 21 & 0.326 & 0.325 & 1.00014 \\
\hline $\mathrm{PS}-\left(\mathrm{NRpe}{ }_{6} \mathrm{Nme}_{42}\right)$ & 88 & $\mathrm{PS}-\left(\mathrm{NRpe}{ }_{5} \mathrm{Nme}_{42}\right)$ & 12 & 0.340 & 0.339 & 1.00008 \\
\hline $\mathrm{PS}-\left(\mathrm{Npe}_{6} \mathrm{Nme}_{27}\right)$ & $>99$ & 1 & 1 & 0.268 & 0.268 & 1.00000 \\
\hline PS- $\left(\mathrm{Npe}_{6} \mathrm{Nme}_{30}\right)$ & $>99$ & 1 & 1 & 0.283 & 0.283 & 1.00000 \\
\hline $\mathrm{PS}-\left(\mathrm{Npe}_{6} \mathrm{Nme}_{32}\right)$ & 87 & Missing the acyl group & 13 & 0.293 & 0.293 & 1.00001 \\
\hline \multirow{2}{*}{ PS- $\left(\mathrm{Npe}_{6} \mathrm{Nme}_{33}\right)$} & \multirow{2}{*}{86} & PS- $-\left(\mathrm{Npe}_{5} \mathrm{Nme}_{33}\right)$ & 7 & \multirow{2}{*}{0.298} & \multirow{2}{*}{0.297} & \multirow{2}{*}{1.00035} \\
\hline & & $\mathrm{PS}-\left(\mathrm{Npe}_{4} \mathrm{Nme}_{33}\right)$ & 7 & & & \\
\hline \multirow[b]{2}{*}{ PS- $\left(\mathrm{Npe}_{6} \mathrm{Nme}_{36}\right)$} & \multirow[b]{2}{*}{86} & PS- $-\left(\mathrm{Npe}_{5} \mathrm{Nme}_{30}\right)$ & 6 & \multirow[b]{2}{*}{0.313} & \multirow[b]{2}{*}{0.311} & \multirow[b]{2}{*}{1.00037} \\
\hline & & $\begin{array}{l}\text { PS- }-\left(\mathrm{Npe}_{4} \mathrm{Nme}_{30}\right) \text {, some } \\
\text { missing the acyl group }\end{array}$ & 8 & & & \\
\hline \multirow{2}{*}{ PS- $\left(\mathrm{Npe}_{6} \mathrm{Nme}_{39}\right)$} & \multirow{2}{*}{86} & $\mathrm{PS}-\left(\mathrm{Npe}_{5} \mathrm{Nme}_{39}\right)$ & 6 & \multirow{2}{*}{0.326} & \multirow{2}{*}{0.325} & \multirow{2}{*}{1.00029} \\
\hline & & PS- $\left(\mathrm{Npe}_{4} \mathrm{Nme}_{39}\right)$ & 8 & & & \\
\hline $\mathrm{PS}-\left(\mathrm{NRpe} \mathrm{Npe}_{3} \mathrm{Nme}_{36}\right)$ & 74 & Missing the acyl group & 26 & 0.299 & 0.298 & 1.00001 \\
\hline $\mathrm{PS}-\left(\mathrm{Npe}_{3} \mathrm{NRpe} \mathrm{Nme}_{36}\right)$ & 80 & Missing the acyl group & 20 & 0.299 & 0.298 & 1.00001 \\
\hline
\end{tabular}

*The low molar mass impurities and species without the last residue (Nprg) will not couple to polystyrene and are removed in prep GPC purifications. Therefore, the purity was estimated based on species that have the last Nprg unit, which will go into the final block copolymers and affect the volume fractions.

\begin{tabular}{ccc} 
& $\mathrm{NRpe}_{6}$ & 2.1 \\
\hline$L_{C}(\mathrm{~nm})$ & 1.2 & 0.6 \\
$l_{p}(\mathrm{~nm})$ & 1.2 & 0.209 \\
$R_{g}{ }^{2}\left(\mathrm{~nm}^{2}\right)$ & 0.099 & 0.127 \\
$4 / 3 R_{g}{ }^{3}\left(\mathrm{~nm}^{3}\right)$ & 0.042 & $\mathrm{Npe}_{6}$ \\
\hline
\end{tabular}

Volume occupied by the interfacial segment of 6 polypeptoid units, either helical or coil, is estimated as $4 / 3 R_{g}{ }^{3}$, with the radius of gyration $\left(R_{g}\right)$ calculated using the wormlike chain model:

$$
\left\langle R_{g}{ }^{2}\right\rangle=\frac{L l_{p}}{3}-l_{p}{ }^{2}+\frac{2 l_{p}{ }^{3}}{L}\left[1-\frac{l_{p}}{L}\left(1-e^{-L / l_{p}}\right)\right]
$$

The contour length, $L_{C}$, and the persistence length, $l_{p}$, are estimated based on results from a previous study. ${ }^{8}$ 


\section{Reference}

1. Wu, C. W.; Sanborn, T. J.; Zuckermann, R. N.; Barron, A. E., Peptoid oligomers with alphachiral, aromatic side chains: Effects of chain length on secondary structure. J. Am. Chem. Soc. 2001, 123 (13), 2958-2963.

2. Murnen, H. K.; Rosales, A. M.; Jaworski, J. N.; Segalman, R. A.; Zuckermann, R. N., Hierarchical Self-Assembly of a Biomimetic Diblock Copolypeptoid into Homochiral Superhelices. $J$. Am. Chem. Soc. 2010, 132 (45), 16112-16119.

3. Stringer, J. R.; Crapster, J. A.; Guzei, I. A.; Blackwell, H. E., Extraordinarily Robust Polyproline Type I Peptoid Helices Generated via the Incorporation of alpha-Chiral Aromatic N-1-Naphthylethyl Side Chains. J. Am. Chem. Soc. 2011, 133 (39), 15559-15567.

4. $\quad$ Greer, D. R.; Stolberg, M. A.; Kundu, J.; Spencer, R. K.; Pascal, T.; Prendergast, D.; Balsara, N. P.; Zuckermann, R. N., Universal Relationship between Molecular Structure and Crystal Structure in Peptoid Polymers and Prevalence of the cis Backbone Conformation. J. Am. Chem. Soc. 2018, 140 (2), 827-833.

5. Greer, D. R.; Stolberg, M. A.; Xuan, S.; Jiang, X.; Balsara, N. P.; Zuckermann, R. N., LiquidCrystalline Phase Behavior in Polypeptoid Diblock Copolymers. Macromolecules 2018, 51 (23), 95199525.

6. Jiang, X.; Xuan, S.; Kundu, J.; Prendergast, D.; Zuckermann, R. N.; Balsara, N. P., Effect of processing and end groups on the crystal structure of polypeptoids studied by cryogenic electron microscopy at atomic length scales. Soft Matter 2019, 15 (23), 4723-4736.

7. Xuan, S.; Jiang, X.; Spencer, R. K.; Li, N. K.; Prendergast, D.; Balsara, N. P.; Zuckermann, R. N., Atomic-level engineering and imaging of polypeptoid crystal lattices. Proc. Natl. Acad. Sci. U.S.A. 2019, 116 (45), 22491.

8. Yu, B.; Danielsen, S. P. O.; Yang, K.-C.; Ho, R.-M.; Walker, L. M.; Segalman, R. A., Insensitivity of Sterically Defined Helical Chain Conformations to Solvent Quality in Dilute Solution. ACS Macro Lett. 2020, 9 (6), 849-854. 